\title{
Environmental, evolutionary, and ecological drivers of slow growth in deep-sea demersal teleosts
}

\author{
Jesse A. Black ${ }^{1, *}$, Anna B. Neuheimer ${ }^{1,2}$, Peter L. Horn ${ }^{3}$, Di M. Tracey ${ }^{3}$, \\ Jeffrey C. Drazen ${ }^{1}$ \\ ${ }^{1}$ Department of Oceanography, School of Ocean Earth Science and Technology, University of Hawaii, Honolulu 96822, USA \\ ${ }^{2}$ Aarhus Institute of Advanced Studies \& Department of Biology, Aarhus University, Aarhus 8000, Denmark \\ ${ }^{3}$ National Institute of Water \& Atmospheric Research Ltd (NIWA), Wellington 6241, New Zealand
}

ABSTRACT: The deep sea (>500 m ocean depth) is the largest global habitat, characterized by cool temperatures, low ambient light, and food-poor conditions relative to shallower waters. Deep-sea teleosts generally grow more slowly than those inhabiting shallow water. However, this is a generalization, and even amongst deep-sea teleosts, there is a broad continuum of growth rates. The importance of potential drivers of growth rate variability amongst deepsea species, such as temperature, food availability, oxygen concentration, metabolic rate, and phylogeny, have yet to be fully evaluated. We present a meta-analysis in which age and size data were collected for 53 species of teleosts whose collective depth ranges span from surface waters to $4000 \mathrm{~m}$. We calculated growth metrics using both calendar and thermal age, and compared them with environmental, ecological, and phylogenetic variables. Temperature alone explained up to $30 \%$ of variation in the von Bertalanffy growth coefficient $\left(K, \mathrm{yr}^{-1}\right)$, and $21 \%$ of the variation in the average annual increase in mass (AIM, \%), a metric of growth prior to maturity. After correcting for temperature effects, depth was still a significant driver of growth, explaining up to 20 and $10 \%$ of the remaining variation in $K$ and AIM, respectively. Oxygen concentration also explained $\sim 11 \%$ of remaining variation in AIM following temperature correction. Relatively minor amounts of variation may be explained by food availability, phylogeny, and the locomotory mode of the teleosts. We also found strong correlation between growth and metabolic rate, which may be an underlying driver also related to temperature, depth, and other factors, or the 2 parameters may simply covary as a result of being linked by evolutionary pressures. Evaluating the influence of ecological and/or envi-
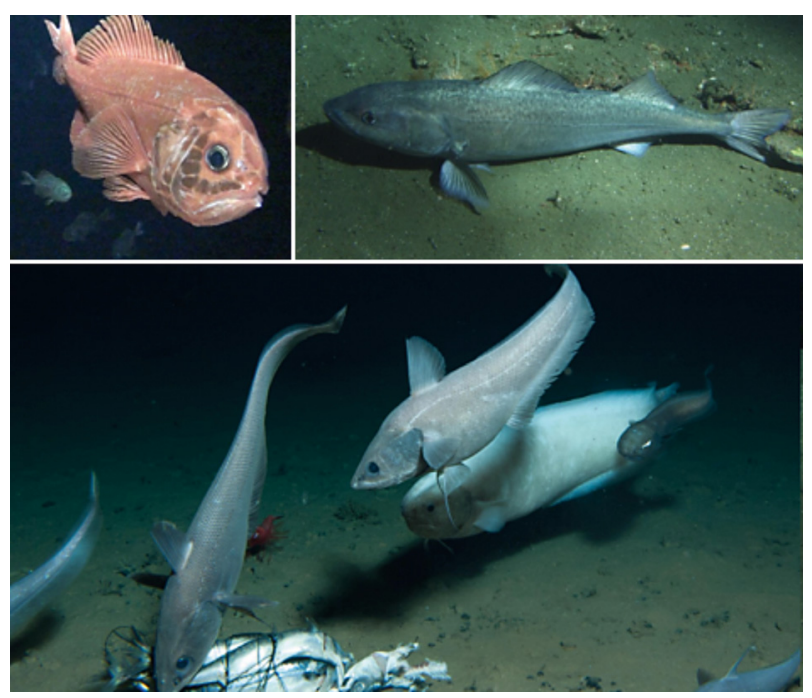

Wide variation in growth, habitat, and ecological role can be found across deep-sea fishes like the abyssal (bottom: Coryphaenoides armatus, Barathrites iris, Bassozetus nasus), the especially long-lived (top left: Hoplostethus atlanticus), and the shelf/slope (top right: Anoplopoma fimbria) species.

Photos: Bottom: Jeff Drazen and Astrid Leitner; Top left: Di Tracey; Top right: NOAA

ronmental drivers of growth is a vital step in understanding both the evolution of life history parameters across the depth continuum as well as their implications for species' resilience to increasing anthropogenic stressors.

KEY WORDS: Fish $\cdot$ Teleost $\cdot$ Growth $\cdot$ Pace of life $\cdot$ Evolution $\cdot$ Life history $\cdot$ Metabolism $\cdot$ Temperature · Deep sea $\cdot$ Demersal $\cdot$ Marine 


\section{INTRODUCTION}

Deep-sea teleosts (referred to hereafter as fishes) generally have high ages-at-maturity, slower growth rates, lower metabolic rates, and greater longevity than shallow-water fishes (Koslow 1996, Caillet et al. 2001, Drazen \& Haedrich 2012). Despite these generalizations, life history parameters vary considerably across the depth continuum. For example, the Patagonian toothfish Dissostichus eleginoides (median depth of $\sim 1100 \mathrm{~m}$ ) matures between 5 and 7 yr of age (Everson \& Murray 1999, Horn 2002), while the black cardinalfish Epigonus telescopus (median depth $~ 800 \mathrm{~m}$ ) matures around 36 yr (Tracey et al. 2000, 2017, Dunn 2009). Differences in longevity, maturity, and growth rate may reflect the cumulative influence of phylogeny, evolutionary pressures such as predation, and a variety of environmental drivers such as pressure, temperature, oxygen, and food availability, all of which change with depth in most ocean habitats.

A variety of environmental drivers, temperature and food supply in particular, may affect growth rates of shallow-water fishes. Temperature has been shown to be a primary driver. The growing degree-day (GDD ${ }^{\circ} \mathrm{C} \times$ day), i.e. the product of habitat temperature and calendar age of fish in days, has successfully explained differences in growth rates across populations of Atlantic cod Gadus morhua and other fishes (Braten \& Guy 2002, Neuheimer \& Taggert 2007, 2010, Venturelli et al. 2010, Shackell et al. 2019). In much of the deep sea, temperature and growth rates decline rapidly with depth, and so temperature has been frequently hypothesized to drive the observed patterns (Drazen \& Haedrich 2012, McClain et al. 2012). Flux of particulate organic carbon (POC), the primary basis of the food web in the deep ocean, also declines exponentially with depth (e.g. Martin et al. 1987, Lutz 2007). Thus, the declining availability of food with depth may also play a role in growth (e.g. Rigby \& Simpfendorfer 2015), as accumulating mass requires energy intake and, at least in aquaculture settings, feeding level has a large influence on growth rates (reviewed in Persson \& De Roos 2006). In fishes' natural environment, however, ecosystemlevel changes in food supply may primarily constrain population size before affecting interspecific growth rate; as available food increases, the carrying capacity of a given population increases, while the amount of energy available to individuals for growth and other biological processes may remain relatively constant, depending on relationships between average body size and foraging efficiency (Sebens 1987, McClain et al. 2012).
Metabolic rate has been found to correlate strongly with growth rates. Metabolic rate, which scales to body mass and temperature, represents the rate of biochemical reactions in the organism (Brown et al. 2004, McClain et al. 2012), including the distribution of biochemical resources into the processes of growth, reproduction, and survival. It is unclear whether metabolic rate mechanistically constrains maximum growth rate (the 'performance model'), or rather represents the fraction of energy devoted to maintenance costs, with the remaining energy diverted to growth and activity (the 'allocation model'), as studies on teleosts have found support for both models (reviewed in Careau et al. 2008). If metabolic rate does positively and causally correlate to growth, then any environmental conditions affecting metabolism would therefore indirectly affect growth rate. Temperature clearly declines with depth in most ocean basins which could then reduce metabolic rates with concurrent reductions in growth rate. Oxygen is a key reactant in aerobic metabolism, and if growth rate is indeed constrained by or linked to metabolic rate, it would follow that aerobic metabolic reactions that facilitate generation of new biomass can only operate as quickly as oxygen can be made available. However, metabolic rate has been shown to be more strongly associated with gill surface area than the ambient concentration of oxygen itself, and thus rapid metabolism and growth in oxygen-poor waters may simply be a matter of possessing specific adaptations for efficient oxygen extraction and delivery (Friedman et al. 2012). Finally, the visual interactions hypothesis suggests that after accounting for temperature and body size effects, the decline in metabolism with depth in fishes (and several midwater groups) to a depth of about $1000 \mathrm{~m}$ reflects a decrease in selective pressure for rapid locomotory capacity as visual predation becomes less common with decreasing light levels (Childress 1995). In short, temperature, oxygen, and light levels may all affect metabolic rate, depending largely on the depth in question, and may therefore be indirect but important drivers of growth.

Many of these variables change with depth, often covarying with one another and/or varying between regions of the ocean (Paulmier \& Ruiz-Pino 2009). Therefore, distinguishing the importance of one factor over another will require knowledge of life histories from multiple regions of the oceans to untangle as much covariation as possible. Studies of age and growth require extensive sampling effort, time, and labor, and these logistical demands increase sharply as deeper dwelling organisms are targeted. The progress of age and growth studies for many deep-sea 
species may therefore be outpaced by anthropogenic impacts, and as such, a predictive framework of growth is required in the short term. To address these factors, we compared life history parameters from studies on populations of deep-sea demersal fishes and some phylogenetically related shallow-water species to environmental variables from each species' habitat to establish a framework for estimating growth patterns and life histories. Similar analyses have been performed on octopods, freshwater fishes, and sharks (Rigby \& Simpfendorfer 2015, Schwarz et al. 2018, de Santana et al. 2020) to explain the effect of temperature and other ecological and environmental variables on life history parameters, but to our knowledge, this is the first meta-analysis to incorporate environmental conditions in explaining growth of marine demersal fishes across depth.

It may be that variation in growth across demersal fishes is not directly explained by environmental conditions. Rather, it may relate to the relatively higher fitness of a 'slow' life history strategy with increasing depth, with the deep sea favoring slow metabolism, low growth rates, and long maturation times relative to the shallows. A spectrum of 'fast vs. slow' life history strategies has been observed across a diversity of animals, with 'faster' organisms tending to have a suite of traits including higher growth rates, faster metabolisms, shorter maturation times, increased mortality, bolder behavior, etc. relative to 'slower' organisms (Mittelbach et al. 2014, Auer et al. 2018, Damsgård et al. 2019; reviewed in Réale et al. 2010). Much of this research has focused on intraspecific patterns, but it may apply to interspecific comparisons too. We discuss the implications of evolutionary drivers even though their quantification is much more challenging than environmental determinants in the deep sea or any environment.

\section{METHODS}

\subsection{Growth data and metrics}

Data on fish growth and life history were extracted from a variety of sources (see Table 1). Forty published studies and 2 national oceanographic institutions (Northwest Fisheries Science Center [NWFSC; accessed via https://www.nwfsc.noaa.gov/data/map] operating out of the USA, and the National Institute of Water and Atmospheric Research [NIWA] out of New Zealand) also provided data. Raw data were used when possible. When raw data were unavailable, data were digitized from plots of age vs. size, or from tables containing mean size-at-age. When available, other relevant spatial and environmental data were also collected, including depth, latitude and longitude, and temperature and/or oxygen concentration measured on the fishing gear. We attempted to minimize the effects of covariation between depth and temperature by collecting data from a global set of locations, including the Mediterranean Sea, where temperature remains relatively constant $\left(\sim 13^{\circ} \mathrm{C}\right)$ across depth. Only teleost fishes were included in this analysis. Chondrichthyans were omitted as there is a scarcity of age data for this group and they have fundamentally different life histories and physiologies (e.g. Treberg \& Speers-Roesch 2016).

All age data used in this meta-analysis originated from counts of otolith annuli. To be accepted for use in our meta-analysis, otoliths must have been at least polished/ground/broken to reveal the central nucleus before age estimation. Age data from whole otoliths has been widely shown to severely underestimate actual fish age for multiple species, particularly those that are long-lived (reviewed in Campana 2001). For this reason, we did not include age data for mature fishes derived from whole otolith age counts, with the only exception being Beryx splendens. Studies have validated the use of whole otoliths as an accurate aging method for $B$. splendens via marginal frequency analysis and direct comparison of annuli counts from whole and sectioned otoliths (Massey \& Horn 1990, Lehodey \& Grandperrin 1996). Some studies in this analysis used whole otoliths to estimate ages of young fish but switched to other methods (break and burn or transverse sectioning) for fish above a particular size. Only studies with age data for at least 90 individual fish were used in this analysis. In some cases, data for more than one population of the same species was collected, and growth parameters and environmental conditions were estimated separately for these distinct populations. The only exception is Coryphaenoides acrolepis. For this species, in order to obtain enough observations to fit growth parameters to age and size data, data were combined from Andrews et al. (1999) and Matsui et al. (1990), which were collected primarily from the California slope with some data from off Oregon and Washington. The catch locations for 7 species from the NWFSC Groundfish Survey, which spans the entire west coast of the USA, were initially split into North and South sections to test for differences in environmental parameters and growth rates between the 2 regions. All these species are mobile, and no evidence for multiple, isolated populations of these fishes along the western USA was found in the literature. Of these 
7 species, only Merluccius productus showed significant differences in growth metrics ( 30\% difference) between fish from north and south of $42.5^{\circ} \mathrm{N}$, so these groups were parameterized as different populations (see Table 1). The rest of the species from the NWFSC Groundfish Survey were parameterized as one contiguous population because no significant differences in growth parameters were found.

Growth rate in fish has been traditionally estimated using the von Bertalanffy (1938) growth curve: $L_{t}=L_{\infty}$ $\left(1-\mathrm{e}^{-K\left[t-t_{0}\right]}\right)$, where $L_{t}$ is length of the fish at time $t$, the $x$-intercept $t_{0}$ is the theoretical age at a length of zero, and $K$ represents the exponential coefficient of growth until a maximum asymptotic length $\left(L_{\infty}\right)$. A larger value of $K$ corresponds to a more rapid increase in length to the maximum length of the fish. These parameters were calculated for each population. Bootstrapped 95\% confidence intervals were calculated for each parameter. For data sets with few young fish, this method can produce biologically improbable curves (e.g. a population with predicted lengths of $\sim 20 \mathrm{~cm}$ at age 0). For this meta-analysis, any von Bertalanffy curve with a $t_{0}$ with absolute value $>2.5$ was recalculated with a $t_{0}$ fixed at -0.5 . Fixing the $t_{0}$ parameter at -0.1 or -0.5 has been employed in growth studies on species with a relative scarcity of juvenile data in order to ensure predicted fish length is positive and nonzero at hatching, producing more biologically realistic values of $K$ (Horn et al. 2012, Horn \& Sutton 2015). Here, we chose -0.5 as the fixed value, though fixing at -0.1 did not yield significantly different $K$ values. Still, parameter values should be observed with some caution (Lorenzen 1996). See Supplement 1 for growth curves and Supplement 2 for parameter values and confidence intervals with and without fixed values of $t_{0}$ (all Supplements for this article are at www.int-res. com/articles/suppl/m658p001_supp/).

Growth was also calculated as an average increase in mass (AIM; as \%) per year during the prematurity phase, to provide an estimate of the maximum rates at which each species can accumulate mass prior to experiencing the energy expenditures associated with reproduction. When available, age at 50\% maturity was collected from the literature (Supplement 2). When age at $50 \%$ maturity was not available, we used the median between minimum and maximum age at maturity or estimated a likely age at maturity from published lengths at maturity using von Bertalanffy growth curves (see Table 1). If the age at maturity differed between sexes, the younger age was used as the cut-off for the end of the prematurity phase. When mass data were not available, predicted mass was calculated from fish length using published length-weight conversions (Supplement 2). For each species, the relationship between age and predicted or observed mass was modeled using a generalized additive model (GAM) to predict mass-at-age during the prematurity phase of growth (error distribution: Gamma). These GAM fits were assessed for their ability to give rise to the data by comparing residuals between data and simulation estimates from 1000 simulations to check for uniformity or outlier errors using the R package 'DHARMa' (Hartig 2019). To avoid overfitting, the complexity of the curve shape was increased incrementally until simulated fits did not produce these errors. A more detailed description of the GAM fitting process is in the 'Supplementary Methods' (Supplement 3). Curves fit for the Atlantic populations of the abyssal Coryphaenoides armatus, the deepest species in our data set, did not meet our thresholds for any fitting approach due to a small data set. However, data for this population was retained to investigate the influence of this abyssal fish on patterns in growth. Results for AIM are reported with and without inclusion of $C$. armatus. To capture only the phase of rapid growth during prematurity, any decline in predicted mass observed as the fish approached maturity was trimmed. The remaining values of predicted mass-atage were then used to calculate the AIM.

Depth ranges were summarized from the literature for each species (Supplement 2). Whenever possible, we used published depth ranges that were estimated in the same general area as the catch locations for studies used for this meta-analysis. Several of the species included in this meta-analysis have improbably wide absolute minimum and maximum depths of occurrence. For example, Antimora rostrata has been observed/collected at depths from 350-3000 m, but generally lives at 1200-2500 m (Cohen et al. 1990, Froese \& Pauly 2019). In order to constrain predictions of temperature, oxygen, and other environmental parameters to conditions likely experienced by most members of each species, we used these narrower, 'usual' depth ranges of high abundance for each species in our analyses rather than the absolute observed depth range (as in Drazen \& Haedrich 2012). When modal histograms of abundance vs. depth were available in the literature, the minimum and maximum depth range was set to where abundance was $25 \%$ of the maximum abundance. This procedure was also used if histograms of presence in percent of tows vs. depth were available (i.e. Anderson et al. 1998). The median value between minimum and maximum usual depths was also used as a predictor. Thus, for each population, this analysis included 3 depth metrics: minimum, median, and maximum usual depth. 
As temperature has been shown to explain a great deal of variation in growth rate in shallow-water species, it was predicted to be a primary driver in both growth metrics, $K$ and AIM. To decouple the effect of temperature from other potential drivers that also closely correlate with increasing depth, temperatureadjusted $K$ and AIM were created by calculating versions of each growth metric using growing degreeyears (GDY, i.e. the integrated thermal age), instead of calendar age. Here we use GDY, the product of fish age in years and predicted temperature of habitat, to obtain a metric of thermal age for each fish. Thermal ages were then used to create temperatureadjusted versions of $K$ and AIM, denoted here as $K_{\mathrm{GDY}}$ and $\mathrm{AIM}_{\mathrm{GDY}}$. These 2 metrics were analyzed alongside $K$ and AIM in statistical analyses with environmental and ecological variables.

Temperature at the location of fish captures was not available in most studies. An average temperature experienced by the fish throughout their lifespan was predicted using data from World Ocean Atlas (WOA) $\left(1^{\circ}\right.$ horizontal resolution with $5 \mathrm{~m}$ vertical resolution near the surface down to $100 \mathrm{~m}$ resolution at abyssal depths, decadal averages from 19552012; Locarnini et al. 2013). Temperature observations across each species' usual depth range at the location of catch were averaged. Species that live in habitats that contradict the inverse relationship of depth and temperature in the world ocean were classified as follows for comparison: cold, shallow-water fishes ( $\leq 300 \mathrm{~m}$ maximum usual depth and $<4^{\circ} \mathrm{C}$ average temperature of habitat) and deep, warm-water fishes $\left(\geq 300 \mathrm{~m}\right.$ minimum usual depth and $>10^{\circ} \mathrm{C}$ average temperature of habitat).

Oxygen concentration $\left(\mathrm{ml} \mathrm{l}^{-1}\right)$ data were gathered from WOA $\left(1^{\circ}\right.$ horizontal resolution with $5 \mathrm{~m}$ vertical resolution near the surface down to $100 \mathrm{~m}$ resolution at abyssal depths, decadal averages from 1955-2012; García et al. 2013). Oxygen concentration observations across each species' usual depth range at the capture locations were averaged.

Estimating food availability is a great challenge and depends upon species-specific feeding preferences and foraging strategies (Drazen \& Sutton 2017) as well as prey population dynamics. This information was lacking for nearly all species in this study. Therefore, we used POC flux to the seafloor estimated by the Lutz model (Lutz et al. 2007) as a proxy for food availability. POC flux has been used as a proxy for food supply in similar, global meta-analyses (Woolley et al. 2016). POC flux is the basal energy source for most seafloor habitats (except chemosynthetic ecosystems), and therefore supports the production of bio- mass in benthic habitats, which is theoretically available for fishes to feed upon. The procedure for estimating POC flux to the seafloor for each individual species' catch location was adapted from methods described by Lutz et al. (2007). Net primary production (NPP) was estimated using global Standard Vertically Generalized Production Model (VGPM) data from Oregon State University's Ocean Productivity portal (www.science.oregonstate.edu/ocean.productivity/ custom.php) at a resolution of $1 / 6^{\text {th }}$ of a degree. Bathymetry was extracted from the Navy ETOPO data base (ETOPO5 $5 \times 5$ minute bathymetry; http://iridl. ldeo.columbia.edu/SOURCES/.WORLDBATH/.bath/ datafiles.html), and any observations of chlorophyll along the $30 \mathrm{~m}$ isobath or shallower were omitted to avoid unnecessary backscatter, as done in previous published estimations of primary production (Gove et al. 2016). NPP at 2 yr intervals across the years 20072017 was averaged across the catch location bounds for each population, resulting in a decadal average value of NPP for each population. Seasonal Variation Index was calculated as described in Lutz et al. (2007). A global average euphotic zone depth of $110 \mathrm{~m}$ was used (Lima et al. 2013). Three separate Lutz POC fluxes were predicted for the minimum, median, and maximum depths for each population within their catch boundaries.

Lutz POC flux is dependent on measurements from sediment traps, which have been found to underestimate the inputs of organic carbon to the seafloor, particularly on continental slopes (Smith 1992, Smith \& Demopoulos 2003). For this reason, we also gathered sediment community oxygen consumption (SCOC) rate data, a measure of remineralization rates of organic material, which has also been used to estimate ecosystem food availability (Jahnke 1996, Stratmann et al. 2019). We used the SCOC database collated by Stratmann et al. (2019) to collect SCOC rates within the bounds of each species' catch location and averaged them at $50 \mathrm{~m}$ intervals across the depth range of each species. These $50 \mathrm{~m}$ binned averages were then averaged to provide a mean SCOC value representative of each entire habitat. As these data are sparse geographically and rely on individual measurements rather than extrapolation from satellite color data, representative lifespan SCOC rates could only be calculated for 21 species.

For a subset of fishes, published data from studies on fish metabolic rate were available for comparison to growth metrics. Specifically, published activities of citrate synthase (CS) enzyme activity for various species were collected (Sullivan \& Somero 1980, Siebenaller et al. 1982, Drazen et al. 2015, Saavedra et al. 
2016, C. N. Trueman \& D. Shores unpubl. data). CS is an enzyme of the Krebs cycle, and its activity has been used in past studies as a proxy for whole animal resting aerobic metabolic rates in fishes (Somero \& Childress 1980, Somero 1990; reviewed in Dahlhoff 2004 and Drazen \& Seibel 2007). Enzyme activities were all measured at a temperature of $10^{\circ} \mathrm{C}$ (denoted $\mathrm{CS}_{10}$ ), and normalized to a mass of $500 \mathrm{~g}$ in order to correct for the scaling effects of body mass on metabolism as described in Gillooly et al. (2001) and Brown et al. (2004). See 'Adjusted metabolic rates to temperature and mass of habitat' in 'Supplementary Methods' in Supplement 3 for equations used. As biochemical reaction rates increase with temperature, CS values were also calculated to reflect metabolic rates at habitat temperature (denoted $\mathrm{CS}_{\mathrm{H}}$ ), as per previous work (Gillooly et al. 2001, Brown et al. 2004, McClain et al. 2012; see Supplement 3 and Section 3.2 below).

The fishes in this meta-analysis, though all demersal, occur on a wide spectrum of activity levels, from the sluggish, sedentary Sebastolobus alascanus to active swimmers like Anoplopoma fimbria. As an additional proxy for activity level, we included a rough categorization of activity level based on locomotory mode: each fish was characterized as benthic if they predominately remain on the seafloor or benthopelagic if they are typically actively swimming above the seafloor. This descriptor was used as a categorical variable in statistical analysis. Locomotory modes were generally assigned based on descriptions for each species in FishBase (see Supplement 2 for all sources and justifications used).

\subsection{Ontogenetic migrators}

Ten species in this meta-analysis are known to ontogenetically migrate deeper with age/size (see Table 1), complicating estimation of environmental predictors. For these fishes, estimation of environmental predictors was modified to account for changes in depth across the fish's lifespan. Environmental predictors were estimated individually, based on the unique depth of each individual fish given its capture depth (or mean size-at-age data point, when only mean size-at-age was available). When individual depth-of-capture was not available, published regressions were used to estimate likely depth at a given size/age. For S. alascanus, published probabilities of depth by length (Jacobson et al. 2001) were used to model predicted length vs. depth (GAM; family: gamma; link: log). When detailed depth information was available (primarily for data from
NWFSC), temperature was estimated for each ontogenetic migrator by collecting WOA temperature data within each study location and using a model (GAM; family: gamma; link: log) to predict temperature based on each ontogenetic migrator's predicted or observed depth and latitude/longitude of catch. This process was repeated to estimate oxygen concentration for each migrator. Lutz POC flux was calculated at the predicted or observed depth of each individual ontogenetic migrator (or mean size-at-age datapoint when only mean data were available). Thus, for each ontogenetically migrating species, mean conditions were available for each year of the species as it moved downslope.

The descriptors 'prematurity' and 'lifespan' are used next to environmental predictors to specify whether the underlying data for ontogenetic migrators reflects their early, relatively shallow-water period of life, or their entire lifespan, respectively. For ontogenetic migrators, these predictors are each effectively weighted by time (years) spent at particular depths/conditions. For non-ontogenetic migrators, these 2 versions are identical, as these fish are expected to be distributed relatively uniformly in age/size across their depth range. Collected SCOC rates within the catch locations and depth ranges of ontogenetic migrators were not numerous enough to create regressions of SCOC vs. depth and predict SCOC at the depth of each individual ontogenetic migrator. To resolve this issue, we averaged SCOC at the prematurity depth range of each ontogenetic migrator (average individual depth of capture or predicted depth during prematurity, $\pm \mathrm{SD}$ of the depth of capture). Data were only sufficient to calculate these prematurity SCOC rates for ontogenetic migrators living along the US west coast (S. alascanus and species collected in the NWFSC Groundfish Trawl Survey; see Table 1). For metabolic rate comparisons, 2 versions of temperature-adjusted CS activities were created by adjusting $\mathrm{CS}_{10}$ values to the temperature experienced by each species across its lifespan ('lifespan $\mathrm{CS}_{\mathrm{H}}{ }^{\prime}$ ), and $\mathrm{CS}$ activity rate adjusted to the prematurity temperature experienced by each species ('prematurity $\mathrm{CS}_{\mathrm{H}}$ '; see 'Adjusted metabolic rates to temperature and mass of habitat' in 'Supplementary Methods' in Supplement 3 for the equations used).

In terms of calculating thermal age for ontogenetic migrators, GDY was calculated to represent shifting temperature regimes across their lifespan by fitting a generalized linear model (GLM) of age vs. predicted or observed temperature (family: gamma; link function: log). In multiple species, males and females were observed to have statistically different $(p<$ 
0.05) age vs. temperature curves, suggesting different rates of downslope migration between sexes. For this reason, separate GLMs were fit to males and females for most ontogenetic migrators. To calculate the cumulative GDY for a fish species, the curve produced by the respective GLM equation for the fish's species and/or sex was integrated with bounds beginning from age 0 up to the individual fish age. This integration produces the area under the age vs. temperature curve, and thus calculates a thermal age for the individual fish that accounts for the shifting thermal regime encountered by these ontogenetic migrators. See Fig. S1 in Supplement 3 for an example of how GDY was calculated for ontogenetic migrators and non-migrators.

\subsection{Statistical analysis}

All growth metrics were compared with all environmental predictors in 2 ways: pairwise GLMs (with gamma error distribution), each containing only one growth metric as response and one environmental variable, and with multivariate generalized linear mixed models (GLMMs; gamma error distribution), each containing one growth metric as response, multiple environmental variables, and a random effect for phylogenetic family. The former method was used primarily to identify which metric of each predictor (i.e. maximum depth vs. median depth, prematurity temperature vs. lifespan temperature, etc.) best explained growth and informed which should be included in subsequent GLMM analysis. As such, the results of these pairwise comparisons are not discussed at length here. The latter approach was used to determine which combinations of predictors (including the null model) best explained the growth rate data. In these analyses, a gamma error distribution was chosen because the long-term growth rates of these animals must be greater than zero, and this error distribution does not allow residuals to be negative. Due to paucity of SCOC and metabolic rate data, these predictors were only analyzed in pairwise regressions, and were not included in the full GLMM analysis. However, to see how much variation could potentially be explained by including metabolic rate data, the top model for explaining each growth rate was rerun including prematurity $\mathrm{CS}_{\mathrm{H}}$, the metabolic rate predictor with the strongest relationships with growth rate in pairwise analysis, as a predictor. Environmental predictors estimated from both the prematurity phase of life and across the entire lifespan were used in the pairwise regressions, as well as in GLMM analysis for $K$ and $K_{\mathrm{GDY}}$. Only prematurity predictors were used in multivariate analysis for AIM and $\mathrm{AIM}_{\mathrm{GDY}}$, as these growth metrics reflect only the prematurity phase of growth. For numerical predictors, either a log link function or inverse link function was used depending on which form of the GLM created residuals that were more evenly distributed and without clear patterns. When a clear difference in residual patterns across link functions was not observed, the model favored by Akaike's information criterion with correction for small sample size (AICc) was chosen. AICc is a scoring method used to rank models without favoring those that are overly complex, as the AICc is decreased with increasing explanatory power but is increased by model complexity. Models with AICc scores within 2 of one another are assumed to be equally likely to be the 'true' model. AICc was used in these analyses in the model selection process to maintain balance between overfitting and underfitting the data.

Mixed model analysis and subsequent model selection was repeated for each growth metric with and without inclusion of the abyssal grenadier C. armatus, as this is the only abyssal fish in the data set and is thus a valuable point of comparison to other fishes,

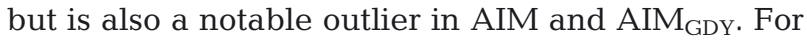
the mixed models where there was more than one version of a predictor (i.e. minimum usual depth vs. median usual depth vs. maximum usual depth), the one that explained the most variation for each growth metric in their respective pairwise regression (see Table 2) was used.

To reduce the influence of covariation among predictors in mixed models, predictors were stepwise removed from each GLMM until the variation inflation factor (VIF) of each predictor was below 3. VIF thresholds of lower than 10 have been suggested, with more conservative cutoffs in high-collinearity data sets set at 2 or 3 (Zuur et al. 2010). The remaining GLMs were each run through the $\mathrm{R}$ function 'dredge' (package 'MuMIn'; Barton 2019), which creates an individual GLMM for every possible permutation of predictors in the global model and returns a table with the models ranked by AICc.

\section{RESULTS}

In total, 74 teleost growth studies or data sources were considered for this meta-analysis. Of these, 21 were eliminated due to use of only whole otoliths and/ or scales in the aging process. Another 12 were eliminated for quality control reasons outlined in the Sup- 
plementary Methods (Supplement 3). Thus, data were included from 42 sources: 40 published studies and 2 national oceanographic institutions (NIWA and NWFSC), representing 53 species over 7 orders of teleost fishes (Table 1). Among these species, 22 are shallow-water fishes (maximum usual depth $<500 \mathrm{~m}$ ), with most others with median depths of 500-3150 m, and a maximum depth of $4000 \mathrm{~m}$ (Fig. 1). Temperatures experienced by these fishes ranged from $1.7-25^{\circ} \mathrm{C}$ (endmembers are Coryphaenoides armatus and Platycephalus indicus, respectively), with 17 species inhabiting waters $>10^{\circ} \mathrm{C}$ (Fig. 1). See Fig. S2 in Supplement 3 for depth and temperature distributions for the 3 most populous orders in our data set. Average oxygen concentrations ranged from $0.5-7.0 \mathrm{ml} \mathrm{l}^{-1}$ (Anoplopoma fimbria and Hippoglossus hippoglossus, respectively; Table 1). Estimated Lutz POC fluxes to each species' habitat ranged from 1.02-26.7 $\mathrm{g} \mathrm{C} \mathrm{m}^{-2}$ $\mathrm{yr}^{-1}$ (Table 1). SCOC rates spanned from 0.45$13.3 \mathrm{mmol} \mathrm{O}_{2} \mathrm{~m}^{-2} \mathrm{~d}^{-1}$ (Supplement 2). Catch locations ranged in latitude from $80^{\circ} \mathrm{S}$ to $66^{\circ} \mathrm{N}$, across the Indian, Atlantic, Pacific, and Southern Ocean regions (Fig. 2). Most catch data were focused in the North Atlantic, Northeast Pacific, and Southwest Pacific. The Mediterranean Sea was the next-most sampled region with 19 growth studies, but as several studies used whole otoliths for age estimation, 15 were rejected for quality control reasons. The low latitudes $\left(\sim 20^{\circ} \mathrm{S}\right.$ to $\left.20^{\circ} \mathrm{N}\right)$ are relatively under-represented, reflecting the availability of data for this study from English-language peer-reviewed literature based in the Asian region. Phylogenetic orders are evenly dispersed across the areas of highest concentration of studies (Fig. 2) but some orders are not found in shallow water (Fig. 1). The age and size data available for some of the species in this meta-analysis were insufficient to robustly compute growth metrics ( $K$ or AIM). These cases are identified in Table 1 and were omitted from analyses.

Moderate covariation was found between some environmental predictors (Fig. 3). Pearson correlation coefficients of temperature and depth had values between -0.43 and -0.51 , depending on the depth bound and whether prematurity or lifespan temperatures were used for ontogenetic migrators. As expected, NPP and POC metrics were all highly positively correlated (Pearson correlation coefficients: 81-87\%). Among all predictors, POC metrics were the most strongly correlated with depth (Pearson correlation coefficients: -0.48 and -0.6$)$. Oxygen was strongly (negatively) correlated only with NPP. Principal component analysis of the prematurity predictors showed NPP and oxygen concentration oriented along the same axis (Fig. 3). Temperature and median depth were fairly aligned and negatively correlated. PC1 and PC2 explained 48.1 and $27.8 \%$ of the variation among environmental predictors, respectively. No obvious clustering was observed among phylogenetic orders, but species inhabiting deep, warm environments (minimum usual depth $>300 \mathrm{~m}$ and average temperature $>10^{\circ} \mathrm{C}$ ) were clustered tightly. These species were all caught in the Mediterranean, likely driving their similar position across environmental characteristics. The 2 shallow, cold-water fish, Gadus morhua and Sebastes marinus (maximum usual depth $<300 \mathrm{~m}$ and average temperature $<4^{\circ} \mathrm{C}$ ), were also clustered closely.

\subsection{Pairwise GLM comparisons: growth rates have strong relationships with temperature, depth, and metabolic rate}

As pairwise comparisons with environmental predictors were primarily used to inform which predictors should be included in the mixed-model analysis and may be highly susceptible to covariation, the results are not discussed at length here (see Figs. S3S5 \& S16 in Supplement 3). We do report results of pairwise comparisons with metabolic rates, as although these data were insufficient to include in the full mixed-model analysis, we found stronger correlations with depth than expected.

Metabolic rate positively correlated with metrics of growth. $K$ and $K_{\mathrm{GDY}}$ increased with CS activity, both measured at $10^{\circ} \mathrm{C}$ and adjusted to each species' habitat temperature $\left(R^{2}=17-32 \%, p<0.05\right.$; Fig. 4). CS activity adjusted to prematurity temperatures explained the greatest amount of variation among the metabolic rate predictors $\left(\mathrm{R}^{2}=27 \%, \mathrm{p}<0.05\right.$ with $C$. armatus, $32 \%$ without $C$. armatus). Beryx splendens was a notable outlier in metabolic rate relative to all metrics of growth (Fig. 4). When B. splendens was omitted from these analyses, metabolic rate was a stronger predictor of $K\left(\mathrm{p}<0.05\right.$ for all metabolic rate metrics, $\mathrm{R}^{2}=20$, 36 , and $41 \%$ for $\mathrm{CS}_{10}$, lifespan $\mathrm{CS}_{\mathrm{H}}$, and prematurity $\mathrm{CS}_{\mathrm{H}}$, respectively) and $K_{\mathrm{GDY}}(\mathrm{p}<0.01$ for all metabolic rate metrics, $\mathrm{R}^{2}=30,40$, and $48 \%$ for $\mathrm{CS}_{10}$, lifespan $\mathrm{CS}_{\mathrm{H}}$ and prematurity $\mathrm{CS}_{\mathrm{H}}$, respectively). CS activities were not significantly related to AIM or $\mathrm{AIM}_{\mathrm{GDY}}$ unless B. splendens was removed from the analysis, in which case there were significant positive relationships $\left(\mathrm{p}<0.001, \mathrm{R}^{2}=37\right.$ and $34 \%$ for AIM vs. lifespan $\mathrm{CS}_{\mathrm{H}}$ and prematurity $\mathrm{CS}_{\mathrm{H}}$, respectively; $\mathrm{p}<0.01, \mathrm{R}^{2}=$ 29,42 , and $37 \%$ for $\mathrm{AIM}_{\mathrm{GDY}}$ vs. $\mathrm{CS}_{10}$, lifespan $\mathrm{CS}_{\mathrm{H}}$, and prematurity $\mathrm{CS}_{\mathrm{H}}$, respectively; Fig. 4). 
Table 1. Depths, habitat variables, and growth metrics for each fish population (see Methods 2.1 and Supplement 2 for sources and explanation of depth ranges). $K$ : von Bertallanfy growth coefficient calculated with length vs. calendar age in years. $K_{\mathrm{GDY}}$ : von Bertallanfy growth coefficient calculated with length vs. thermal age in growing degree-years. AIM: average increase in fish mass between calendar years during the prematurity growth phase. $\mathrm{AIM}_{\mathrm{GDY}}$ : average increase in fish mass between thermal growing degree-years during the prematurity growth phase. $\mathrm{A}_{\mathrm{M}}$ : age at $50 \%$ maturity unless otherwise noted with the following subscripts: a: median of known minimum and maximum ages at maturity; b: estimated using a published length at $50 \%$ maturity and the von Bertalanffy curve; c: general time at maturity. Lutz particulate organic carbon (POC) flux is reported as 3 values separated left to right by slashes as values at minimum, median, and maximum depths; sediment community oxygen consumption (SCOC) values are below POC flux in italics. $\mathrm{CS}_{\mathrm{H}}$ : citrate synthase activity (units per gram wet weight of white muscle tissue at each species' average prematurity temperature). Ontogenetic migrators are underlined, and the prematurity version of applicable predictors are in square brackets. Sebastes mentella is not classified as an ontogenetic migrator here, but sampling was performed at 2 locations with slightly different temperatures, and so has a different prematurity temperature. Asterisks denote where there was insufficient data to calculate growth metrics; dashes indicate data not available. Number of fish represented in data from each study listed under $\mathrm{n}$. Only observations containing both age and size are counted here. Data for $M$. productus contained many more observations of mass-at-age than of length-at-age, denoted with (L) for length observations and (M) for mass

\begin{tabular}{|c|c|c|c|c|c|c|c|c|c|c|c|c|c|}
\hline & $\begin{array}{c}\text { Min. } \\
(\mathrm{m})\end{array}$ & $\begin{array}{l}\text { - Depth - } \\
\text { Median } \\
\quad \text { (m) }\end{array}$ & $\begin{array}{c}\operatorname{Max} . \\
(\mathrm{m})\end{array}$ & $\begin{array}{l}\text { Lutz POC flux } \\
\left(\mathrm{mg} \mathrm{C} \mathrm{m}^{-2} \mathrm{~d}^{-1}\right) \\
\text { SCOC } \\
\left(\mathrm{O}_{2} \mathrm{~m}^{-2} \mathrm{~d}^{-1}\right)\end{array}$ & $\begin{array}{c}\mathrm{O}_{2} \\
\left(\mathrm{ml} \mathrm{l}^{-1}\right)\end{array}$ & $\begin{array}{c}\mathrm{T} \\
\left({ }^{\circ} \mathrm{C}\right)\end{array}$ & $K$ & $K_{\mathrm{GDY}}$ & $\begin{array}{c}\text { AIM } \\
(\%)\end{array}$ & $\begin{array}{c}\mathrm{AIM}_{\mathrm{GDY}} \\
(\%)\end{array}$ & $\mathrm{CS}_{\mathrm{H}}$ & $\mathrm{A}_{\mathrm{M}}$ & $\mathrm{n}$ \\
\hline \multicolumn{14}{|l|}{ Beryciformes } \\
\hline $\begin{array}{l}\text { Charleston Bump } \\
\text { (Friess \& Sedberry 2011) }\end{array}$ & 368 & 432 & 496 & $7.7 / 7.3 / 7.0$ & 4 & 15.2 & 0.12 & 0.007 & * & * & - & 4 & 155 \\
\hline \multicolumn{14}{|l|}{ Beryx splendens } \\
\hline Palliser Bank, NZ (NIWA) & 200 & 500 & 800 & $\begin{array}{c}33 / 26 / 21 \\
10\end{array}$ & 5 & 9 & 0.22 & 0.021 & 33.1 & 2.34 & 3.41 & $5_{b}$ & 2310 \\
\hline \multicolumn{14}{|l|}{ Hoplostethus atlanticus } \\
\hline $\begin{array}{l}\text { Walter's Shoal, SW Indian } \\
\text { Ocean (NIWA) }\end{array}$ & 1000 & 1125 & 1250 & $6.9 / 6.4 / 5.9$ & 4.5 & 5.4 & 0.06 & 0.007 & * & * & 0.5 & 22 & 409 \\
\hline $\begin{array}{l}\text { Hoplostethus mediterraneus } \\
\text { Eastern Mediterranean } \\
\text { (D'Onghia et al. 1998) }\end{array}$ & 388 & 642.5 & 897 & $8.2 / 7.0 / 6.0$ & 4.4 & 13.9 & 0.21 & 0.013 & 72.7 & 4.33 & - & 4 & 419 \\
\hline \multicolumn{14}{|l|}{ Gadiformes } \\
\hline $\begin{array}{l}\text { North Atlantic } \\
\text { (Orlov et al. 2018) }\end{array}$ & $\begin{array}{l}1300 \\
{[880]}\end{array}$ & $\begin{array}{l}1900 \\
{[960]}\end{array}$ & $\begin{array}{c}2500 \\
{[1045]}\end{array}$ & $\begin{array}{c}9.5 \\
{[12.4]}\end{array}$ & 6.6 & $\begin{array}{c}3.5 \\
{[3.7]}\end{array}$ & 0.06 & 0.007 & 24.2 & 3.2 & 0.21 & 16 & 340 \\
\hline $\begin{array}{l}\text { Coelorinchus caelorhincus } \\
\text { Eastern Mediterranean } \\
\text { (Labropoulou \& } \\
\text { Papaconstantinou 2000) }\end{array}$ & 350 & 450 & 550 & $8.4 / 7.9 / 7.4$ & 4.5 & 14.1 & 0.05 & 0.003 & 116.3 & 4.58 & - & 6 & 244 \\
\hline $\begin{array}{l}\text { Coryphaenoides acrolepis } \\
\text { West coast USA (Matsui et al. } \\
\text { 1990, Andrews et al. 1999) } \\
\text { Coryphaenoides armatus }\end{array}$ & 700 & 1350 & 2000 & $\begin{array}{c}18 / 11 / 7.5 \\
2.4\end{array}$ & 0.9 & 3.1 & 0.05 & 0.007 & 9.7 & 1.5 & 0.51 & $36_{a}$ & 146 \\
\hline $\begin{array}{l}\text { Mid-Atlantic Ridge } \\
\text { (Bergstad 2013) }\end{array}$ & 2000 & 3000 & 4000 & $6.9 / 4.0 / 2.8$ & 6.3 & 2.9 & 0.04 & 0.007 & 36.5 & 5.23 & 1.04 & $20_{\mathrm{c}}$ & 317 \\
\hline $\begin{array}{l}\text { Station M } \\
\text { (Gerringer et al. 2018) }\end{array}$ & 2000 & 3150 & 4300 & $\begin{array}{l}6.3 / 4.3 / 3.5 \\
\quad 0.45\end{array}$ & 2.7 & 1.7 & $*$ & * & 15.3 & 3.04 & 1.04 & $20_{\mathrm{c}}$ & 107 \\
\hline $\begin{array}{l}\text { Coryphaenoides rupestris } \\
\text { British Isles } \\
\text { (Allain \& Lorance 2000) }\end{array}$ & 400 & 950 & 1500 & $34.4 / 21 / 13$ & 5.5 & 7.6 & 0.04 & 0.004 & 17.1 & 1.48 & 0.3 & 10 & 2814 \\
\hline $\begin{array}{l}\text { Gadus morhua } \\
\text { North Atlantic } \\
\text { (Rideout et al. 2016) }\end{array}$ & 50 & 125 & 200 & $34 / 32 / 30$ & 6.2 & 3.2 & 0.13 & 0.022 & 40 & 6.47 & - & 5 & 7781062 \\
\hline $\begin{array}{l}\text { Hymenocephalus italicus } \\
\text { Eastern Mediterranean } \\
\text { (D'Onghia et al. 2000) }\end{array}$ & 305 & 601 & 897 & $9.7 / 8.0 / 6.6$ & 4.4 & 13.9 & 0.18 & 0.011 & 78 & 3.46 & - & 3 & 408 \\
\hline
\end{tabular}


Table 1 (continued)

\begin{tabular}{|c|c|c|c|c|c|c|c|c|c|c|c|c|c|}
\hline & $\begin{array}{c}\text { Min. } \\
(\mathrm{m})\end{array}$ & $\begin{array}{l}\text { Depth - } \\
\text { Median } \\
\quad(\mathrm{m})\end{array}$ & $\begin{array}{c}\operatorname{Max} . \\
(\mathrm{m})\end{array}$ & $\begin{array}{l}\text { Lutz POC flux } \\
\left(\mathrm{mg} \mathrm{C} \mathrm{m}^{-2} \mathrm{~d}^{-1}\right) \\
\mathrm{SCOC}^{-1} \\
\left(\mathrm{O}_{2} \mathrm{~m}^{-2} \mathrm{~d}^{-1}\right)\end{array}$ & $\begin{array}{c}\mathrm{O}_{2} \\
\left(\mathrm{ml} \mathrm{l}^{-1}\right)\end{array}$ & $\begin{array}{c}\mathrm{T} \\
\left({ }^{\circ} \mathrm{C}\right)\end{array}$ & $K$ & $K_{\mathrm{GDY}}$ & $\begin{array}{l}\text { AIM } \\
(\%)\end{array}$ & $\begin{array}{l}\mathrm{AIM}_{\mathrm{GDY}} \\
(\%)\end{array}$ & $\mathrm{CS}_{\mathrm{H}}$ & $\mathrm{A}_{\mathrm{M}}$ & $\mathrm{n}$ \\
\hline \multicolumn{14}{|l|}{ Lepidion eques } \\
\hline $\begin{array}{l}\text { North Atlantic } \\
\text { (Magnússon 2001) }\end{array}$ & 500 & 700 & 900 & $31 / 26 / 21$ & 6.1 & $\begin{array}{c}5.8 \\
{[6.4]}\end{array}$ & 0.1 & 0.006 & 43.9 & 3.99 & - & 9 & 295 \\
\hline $\begin{array}{l}\text { Macrourus carinatus } \\
\text { Heard Island } \\
\text { (Van Wijk et al. 2003) }\end{array}$ & 500 & 750 & 1000 & $11 / 8.7 / 6.9$ & 4.4 & 2.3 & 0.07 & 0.013 & 19.3 & 3.43 & - & 11 & 142 \\
\hline $\begin{array}{l}\text { Macruronus novaezelandiae } \\
\text { Off New Zealand } \\
\text { (Horn \& Sullivan 1996) }\end{array}$ & 200 & 500 & 800 & $\begin{array}{c}39 / 31 / 25 \\
4.6\end{array}$ & 5.1 & 9.2 & 0.17 & 0.014 & 43 & 2.94 & - & 6 & 9569 \\
\hline $\begin{array}{l}\text { Merluccius australis } \\
\text { West Coast South Island } \\
\text { (NIWA) }\end{array}$ & 300 & 700 & 1100 & $\begin{array}{c}25 / 18 / 14 \\
3.1\end{array}$ & 4.6 & 7.7 & 0.22 & 0.02 & 49.6 & 3.6 & - & 6 & 3884 \\
\hline $\begin{array}{l}\text { Merluccius hubbsi } \\
\text { Off Brazil } \\
\text { (Vaz-dos-Santos et al. 2007) }\end{array}$ & 100 & 150 & 200 & $16 / 16 / 15$ & 5 & 18 & 0.19 & 0.009 & * & 5.67 & - & 2 & 685 \\
\hline $\begin{array}{l}\text { Merluccius merluccius } \\
\text { Iberian Peninsula } \\
\text { (Piñeiro \& Saínza 2003) }\end{array}$ & 70 & 220 & 370 & $41 / 36 / 31$ & 6.6 & 12.6 & 0.1 & 0.007 & * & $*$ & - & 3 & 965 \\
\hline $\begin{array}{l}\text { Merluccius productus } \\
\text { Northern West Coast USA } \\
\text { (NWFSC Groundfish } \\
\text { Trawl Survey) }\end{array}$ & $\begin{array}{c}50 \\
{[120]}\end{array}$ & $\begin{array}{c}275 \\
{[170]}\end{array}$ & $\begin{array}{c}500 \\
{[220]}\end{array}$ & $\begin{array}{l}67[67] \\
7.3[7.7]\end{array}$ & $\begin{array}{c}3.1 \\
{[3.0]}\end{array}$ & $\begin{array}{c}7.1 \\
{[7.2]}\end{array}$ & 0.27 & 0.025 & 122.6 & 7.22 & 1.52 & 3 & $\begin{array}{c}5501[\mathrm{M}] \\
556[\mathrm{~L}]\end{array}$ \\
\hline $\begin{array}{l}\text { Southern West Coast USA } \\
\text { (NWFSC Groundfish } \\
\text { Trawl Survey) }\end{array}$ & $\begin{array}{c}50 \\
{[170]}\end{array}$ & $\begin{array}{c}275 \\
{[190]}\end{array}$ & $\begin{array}{c}500 \\
{[210]}\end{array}$ & $\begin{array}{l}36[37] \\
11[4.4]\end{array}$ & $\begin{array}{c}2.4 \\
{[2.6]}\end{array}$ & $\begin{array}{c}7.5 \\
{[7.9]}\end{array}$ & 0.2 & 0.019 & 88.3 & 5.91 & 1.65 & 3 & $\begin{array}{c}4475[\mathrm{M}] \\
687[\mathrm{~L}]\end{array}$ \\
\hline $\begin{array}{l}\text { Micromesistius australis } \\
\text { Off Argentina } \\
\text { (Cassia 2000) }\end{array}$ & 70 & 200 & 620 & $64 / 56 / 37$ & 6.4 & 4.5 & 0.17 & 0.023 & 81.2 & 8.16 & - & $4_{\mathrm{b}}$ & 4919 \\
\hline $\begin{array}{l}\text { Off New Zealand } \\
\text { (NIWA) }\end{array}$ & 400 & 500 & 600 & $13 / 12 / 11$ & 5.8 & 5.8 & 0.2 & 0.022 & 96.7 & 7.76 & - & 3 & 7920 \\
\hline $\begin{array}{l}\text { Mora moro } \\
\text { Chatham Rise } \\
\text { (Sutton et al. 2010) }\end{array}$ & 500 & 750 & 1000 & $23 / 18 / 15$ & 5 & 6.3 & 0.13 & 0.014 & 42.8 & 3.81 & 0.34 & $8_{c}$ & 294 \\
\hline $\begin{array}{l}\text { Nezumia sclerorhynchus } \\
\text { Eastern Mediterranean } \\
\text { (Labropoulou \& } \\
\text { Papaconstantinou 2000) }\end{array}$ & 350 & 550 & 750 & $8.4 / 7.4 / 6.6$ & 4.5 & 14.1 & 0.15 & 0.009 & 42.5 & 1.97 & - & 11 & 200 \\
\hline $\begin{array}{l}\text { Trachyrhynchus scabrus } \\
\text { Western Mediterranean } \\
\text { (Massutí et al. 1995) }\end{array}$ & 700 & 875 & 1050 & $11 / 9.4 / 8.4$ & 4.3 & 13.3 & 0.15 & 0.009 & * & * & - & $4_{\mathrm{b}}$ & 263 \\
\hline $\begin{array}{l}\text { Ophidiiformes } \\
\text { Genypterus blacodes }\end{array}$ & & & & & & & & & & & & & \\
\hline Campbell Plateau, NZ (NIWA) & 200 & 500 & 800 & $13 / 10 / 8$ & 5.8 & 6.6 & 0.15 & 0.015 & 65.7 & 5.31 & - & 6 & 5254 \\
\hline Chatham Rise, NZ (NIWA) & 200 & 500 & 800 & $\begin{array}{c}28 / 22 / 17 \\
4.2\end{array}$ & 5.5 & 7.3 & 0.12 & 0.011 & 66.8 & 5.05 & - & 6 & 5751 \\
\hline $\begin{array}{l}\text { Perciformes } \\
\text { Cheilodactylus spectabilis }\end{array}$ & & & & & & & & & & & & & \\
\hline $\begin{array}{l}\text { Tasmania } \\
\text { (Ewing et al. 2007) }\end{array}$ & 0 & 25 & 50 & $34 / 33 / 33$ & 5.6 & 15.3 & 0.39 & 0.026 & 57.7 & 2.54 & - & 3 & 198 \\
\hline
\end{tabular}


Table 1 (continued)

\begin{tabular}{|c|c|c|c|c|c|c|c|c|c|c|c|c|c|}
\hline & $\begin{array}{c}\text { Min. } \\
(\mathrm{m})\end{array}$ & $\begin{array}{l}\text { - Depth - } \\
\text { Median } \\
\quad(\mathrm{m})\end{array}$ & $\begin{array}{c}\operatorname{Max} . \\
(\mathrm{m})\end{array}$ & $\begin{array}{l}\text { Lutz POC flux } \\
\left(\mathrm{mg} \mathrm{C} \mathrm{m}^{-2} \mathrm{~d}^{-1}\right) \\
\mathrm{SCOC}^{-1} \\
\left(\mathrm{O}_{2} \mathrm{~m}^{-2} \mathrm{~d}^{-1}\right)\end{array}$ & $\begin{array}{c}\mathrm{O}_{2} \\
\left(\mathrm{ml} \mathrm{l}^{-1}\right)\end{array}$ & $\begin{array}{c}\mathrm{T} \\
\left({ }^{\circ} \mathrm{C}\right)\end{array}$ & $K$ & $K_{\mathrm{GDY}}$ & $\begin{array}{l}\text { AIM } \\
(\%)\end{array}$ & $\begin{array}{c}\mathrm{AIM}_{\mathrm{GDY}} \\
(\%)\end{array}$ & $\mathrm{CS}_{\mathrm{H}}$ & $\mathrm{A}_{\mathrm{M}}$ & $\mathrm{n}$ \\
\hline \multicolumn{14}{|l|}{ Epigonus telescopus } \\
\hline $\begin{array}{l}\text { Off New Zealand } \\
\text { (Tracey et al. 2000) }\end{array}$ & 500 & 800 & 1000 & $\begin{array}{c}15 / 12 / 10 \\
100\end{array}$ & 4.8 & 7.2 & 0.04 & 0.004 & 5.7 & 0.54 & - & 36 & 554 \\
\hline $\begin{array}{l}\text { Hyperoglyphe perciformis } \\
\text { Charleston Bump } \\
\text { (Filer \& Sedberry 2008) }\end{array}$ & 200 & 363 & 526 & $10 / 8.8 / 7.8$ & 4.1 & 16.1 & 0.21 & 0.012 & 9.2 & 0.46 & - & 6 & 710 \\
\hline \multicolumn{14}{|l|}{$\begin{array}{l}\text { Pleuronectiformes } \\
\text { Atheresthes stomias }\end{array}$} \\
\hline $\begin{array}{l}\overline{\text { West coast USA }} \\
\text { (NWFSC Groundfish } \\
\text { Trawl Survey) }\end{array}$ & $\begin{array}{c}27 \\
{[130]}\end{array}$ & $\begin{array}{l}148.5 \\
{[170]}\end{array}$ & $\begin{array}{c}270 \\
{[210]}\end{array}$ & $\begin{array}{l}51[55] \\
7.7[7.6]\end{array}$ & $\begin{array}{c}1.4 \\
{[1.7]}\end{array}$ & $\begin{array}{c}6.4 \\
{[7.6]}\end{array}$ & 0.14 & 0.012 & 33.2 & 2.68 & 0.46 & 7 & 3525 \\
\hline $\begin{array}{l}\text { Cynoglossus zanzibarensis } \\
\text { South Africa } \\
\text { (Booth \& Walmsley-Hart 2000) }\end{array}$ & 30 & 230 & 430 & $59 / 50 / 43$ & 4.7 & 14.8 & 0.44 & 0.025 & 100.6 & 4.05 & - & 2 & 180 \\
\hline \multicolumn{14}{|l|}{ Eopsetta jordani } \\
\hline $\begin{array}{l}\overline{\text { West coast USA }} \\
\text { (NWFSC Groundfish } \\
\text { Trawl Survey) }\end{array}$ & $\begin{array}{c}160 \\
{[80]}\end{array}$ & $\begin{array}{c}205 \\
{[100]}\end{array}$ & $\begin{array}{c}250 \\
{[120]}\end{array}$ & $\begin{array}{l}46[51] \\
7.0[9.2]\end{array}$ & $\begin{array}{c}3.1 \\
{[4.1]}\end{array}$ & $\begin{array}{c}8.4 \\
{[10.6]}\end{array}$ & 0.13 & 0.009 & 39.7 & 2.75 & 0.64 & 5 & 4745 \\
\hline $\begin{array}{l}\text { Hippoglossus hippoglossus } \\
\text { North Atlantic } \\
\text { (Armsworthy \& } \\
\text { Campana 2010) }\end{array}$ & 55 & 81.5 & 108 & $47 / 45 / 44$ & 7 & 6.2 & 0.13 & 0.014 & 186.1 & 6.69 & - & 6 & 2429 \\
\hline $\begin{array}{l}\text { Microstomus pacificus } \\
\text { West coast USA } \\
\text { (NWFSC Groundfish } \\
\text { Trawl Survey) }\end{array}$ & $\begin{array}{c}55 \\
{[110]}\end{array}$ & $\begin{array}{l}777.5 \\
{[180]}\end{array}$ & $\begin{array}{l}1500 \\
{[250]}\end{array}$ & $\begin{array}{l}31[43] \\
5.4[8.2]\end{array}$ & $\begin{array}{c}1.1 \\
{[3.3]}\end{array}$ & $\begin{array}{c}5.3 \\
{[8.8]}\end{array}$ & 0.17 & 0.017 & 23.3 & 2.1 & 0.78 & 7 & 6020 \\
\hline $\begin{array}{l}\text { Parophrys vetulus } \\
\text { West coast USA } \\
\text { (NWFSC Groundfish } \\
\text { Trawl Survey) }\end{array}$ & $\begin{array}{c}40 \\
{[70]}\end{array}$ & $\begin{array}{l}120 \\
{[90]}\end{array}$ & $\begin{array}{c}200 \\
{[110]}\end{array}$ & $\begin{array}{l}49[51] \\
11[6.4]\end{array}$ & $\begin{array}{c}3.8 \\
{[4.2]}\end{array}$ & $\begin{array}{c}9.2 \\
{[10.6]}\end{array}$ & 0.35 & 0.028 & 61.6 & 3.31 & 0.85 & $4_{\mathrm{a}}$ & 772 \\
\hline $\begin{array}{l}\text { Reinhardtius hippoglossoides } \\
\text { North Atlantic } \\
\text { (Dwyer et al. 2016) }\end{array}$ & 500 & 750 & 1000 & $23 / 18 / 14$ & 6.7 & 2 & 0.07 & 0.015 & 58.4 & 9.78 & - & 10 & 266 \\
\hline $\begin{array}{l}\text { Scorpaeniformes } \\
\text { Anoplopoma fimbria }\end{array}$ & & & & & & & & & & & & & \\
\hline $\begin{array}{l}\text { West coast USA } \\
\text { (NWFSC Groundfish } \\
\text { Trawl Survey) }\end{array}$ & $\begin{array}{c}200 \\
{[140]}\end{array}$ & $\begin{array}{c}600 \\
{[270]}\end{array}$ & $\begin{array}{l}1000 \\
{[390]}\end{array}$ & $\begin{array}{l}26[40] \\
4.4[6.2]\end{array}$ & $\begin{array}{c}0.7 \\
{[2.7]}\end{array}$ & $\begin{array}{c}4.3 \\
{[7.4]}\end{array}$ & 0.43 & 0.045 & 61.4 & 4.87 & 1.67 & 5 & 3772 \\
\hline $\begin{array}{l}\text { Chelidonichthys capensis } \\
\text { South Africa } \\
\text { (McPhail 1998) }\end{array}$ & 30 & 115 & 200 & $42 / 39 / 37$ & 4.7 & 14.8 & 0.07 & 0.004 & 75.2 & 3.31 & - & 4 & 383 \\
\hline $\begin{array}{l}\text { Chelidonichthys queketti } \\
\text { South Africa } \\
\text { (Booth 1997) }\end{array}$ & 50 & 100 & 150 & $38 / 36 / 35$ & 4.7 & 14.8 & 0.4 & 0.022 & $*$ & * & - & 2 & 227 \\
\hline $\begin{array}{l}\text { Helicolenus percoides } \\
\text { Off New Zealand } \\
\text { (Paul \& Horn 2009) }\end{array}$ & 100 & 400 & 700 & $\begin{array}{c}37 / 29 / 22 \\
4.7\end{array}$ & 5.4 & 8.8 & 0.1 & 0.009 & 53.9 & 3.73 & - & 5 & 1338 \\
\hline $\begin{array}{l}\text { Platycephalus indicus } \\
\text { Japan } \\
\text { (Akita \& Tachihara 2019) }\end{array}$ & 0 & 15 & 30 & $12 / 12 / 2012$ & 4.8 & 25 & 0.38 & 0.014 & 118.7 & 2.78 & - & 2 & 351 \\
\hline
\end{tabular}


Table 1 (continued)

\begin{tabular}{|c|c|c|c|c|c|c|c|c|c|c|c|c|c|}
\hline & $\begin{array}{c}\text { Min. } \\
(\mathrm{m})\end{array}$ & $\begin{array}{l}\text { Depth - } \\
\text { Median } \\
\quad(\mathrm{m})\end{array}$ & $\begin{array}{c}\operatorname{Max} . \\
(\mathrm{m})\end{array}$ & $\begin{array}{c}\text { Lutz POC flux } \\
\left(\mathrm{mg} \mathrm{C} \mathrm{m}^{-2} \mathrm{~d}^{-1}\right) \\
\text { SCOC } \\
\left(\mathrm{O}_{2} \mathrm{~m}^{-2} \mathrm{~d}^{-1}\right)\end{array}$ & $\begin{array}{c}\mathrm{O}_{2} \\
\left(\mathrm{ml} \mathrm{l}^{-1}\right)\end{array}$ & $\begin{array}{c}\mathrm{T} \\
\left({ }^{\circ} \mathrm{C}\right)\end{array}$ & $K$ & $K_{\mathrm{GDY}}$ & $\begin{array}{c}\text { AIM } \\
(\%)\end{array}$ & $\begin{array}{c}\mathrm{AIM}_{\mathrm{GDY}} \\
(\%)\end{array}$ & $\mathrm{CS}_{\mathrm{H}}$ & $\mathrm{A}_{\mathrm{M}}$ & $\mathrm{n}$ \\
\hline $\begin{array}{l}\text { Pterois volitans } \\
\text { Gulf of Mexico } \\
\text { (Fogg 2017) }\end{array}$ & 50 & 85 & 120 & $\begin{array}{c}24 / 23 / 22 \\
5.3\end{array}$ & 4.2 & 20.8 & 0.44 & 0.018 & 163.5 & 5.92 & - & 1 & 1576 \\
\hline $\begin{array}{l}\text { Scorpaena notata } \\
\text { Eastern Mediterranean } \\
\text { (Scarcella et al. 2011) }\end{array}$ & 30 & 365 & 700 & $\begin{array}{c}51 / 38 / 29 \\
13\end{array}$ & 5.1 & 13.4 & 0.32 & 0.019 & 59 & 2.85 & - & 2.5 & 225 \\
\hline $\begin{array}{l}\text { Sebastes crameri } \\
\text { West coast USA } \\
\text { (Nichol 1990) }\end{array}$ & 140 & 175 & 210 & $\begin{array}{c}73 / 71 / 69 \\
6.3\end{array}$ & 2.9 & 7.6 & 0.2 & 0.019 & 75.9 & 5.66 & 0.49 & 5 & 1060 \\
\hline $\begin{array}{l}\text { Sebastes ensifer } \\
\text { West coast USA } \\
\text { (Love et al. 2018) }\end{array}$ & 45 & 205.5 & 366 & $62 / 54 / 47$ & 3.1 & 8.7 & 0.13 & 0.012 & 23.7 & 1.91 & - & 9 & 171 \\
\hline $\begin{array}{l}\text { Sebastes fasciatus } \\
\text { Flemish Cap } \\
\text { (Saborido-Rey et al. 2004) }\end{array}$ & 130 & 315 & 500 & $34 / 28 / 24$ & 6.3 & 3.9 & 0.13 & 0.018 & * & * & - & 6 & 5174 \\
\hline $\begin{array}{l}\text { Sebastes marinus } \\
\text { Flemish Cap } \\
\text { (Saborido-Rey et al. 2004) }\end{array}$ & 100 & 200 & 300 & $35 / 32 / 29$ & 6.3 & 3.9 & 0.07 & 0.009 & 52.1 & 6.15 & - & 7 & 6016 \\
\hline $\begin{array}{l}\text { Sebastes melanostomus } \\
\text { West coast USA } \\
\text { (Stevens et al. 2004) }\end{array}$ & 250 & 425 & 600 & $\begin{array}{c}40 / 35 / 30 \\
3.1\end{array}$ & 1 & 6.4 & 0.06 & 0.007 & 7.9 & 0.82 & 0.32 & 34 & 332 \\
\hline $\begin{array}{l}\text { Sebastes mentella } \\
\text { Irminger } \\
\text { (Stransky et al. 2005) }\end{array}$ & 300 & 600 & 900 & $29 / 22 / 16$ & 6.7 & $\begin{array}{c}3.8 \\
{[4.1]}\end{array}$ & 0.13 & 0.02 & 10.2 & 1.58 & - & 10 & 359 \\
\hline $\begin{array}{l}\text { Newfoundland } \\
\text { (Saborido-Rey et al. 2004) }\end{array}$ & 300 & 600 & 900 & $29 / 22 / 17$ & 6.5 & 3.7 & 0.11 & 0.016 & 27.8 & 3.64 & - & 10 & 8930 \\
\hline $\begin{array}{l}\text { Sebastes mystinus } \\
\text { British Isles } \\
\text { (Laidig et al. 2003) }\end{array}$ & 0 & 45 & 90 & $70 / 67 / 65$ & 5.2 & 11.1 & 0.22 & 0.015 & 89.9 & 4.67 & 0.76 & 6 & 1245 \\
\hline $\begin{array}{l}\text { Sebastes simulator } \\
\text { West coast USA } \\
\text { (Love et al. 2018) }\end{array}$ & 99 & 274.5 & 450 & $59 / 51 / 44$ & 1.7 & 7.8 & 0.1 & 0.009 & 30.4 & 2.53 & - & 11 & 156 \\
\hline $\begin{array}{l}\text { Sebastolobus alascanus } \\
\text { Off California } \\
\text { (Kline 1996) }\end{array}$ & $\begin{array}{c}90 \\
{[380]}\end{array}$ & $\begin{array}{c}750 \\
{[380]}\end{array}$ & $\begin{array}{l}1500 \\
{[380]}\end{array}$ & $\begin{array}{c}31[42] \\
4.3\end{array}$ & $\begin{array}{c}0.5 \\
{[1.16]}\end{array}$ & $\begin{array}{c}4.4 \\
{[6.0]}\end{array}$ & 0.02 & 0.002 & 21.8 & 2.26 & 0.4 & 12 & 1140 \\
\hline $\begin{array}{l}\text { Sebastolobus altivelis } \\
\text { Off California } \\
\text { (Kline 1996) }\end{array}$ & 400 & 950 & 1500 & $\begin{array}{c}47 / 30 / 21 \\
1.4\end{array}$ & 0.7 & 4.2 & 0.06 & 0.008 & * & * & 0.21 & $6_{\mathrm{c}}$ & 342 \\
\hline $\begin{array}{l}\text { Zeiformes } \\
\text { Allocyttus niger } \\
\text { Chatham Rise } \\
\text { (NIWA) }\end{array}$ & $\begin{array}{c}700 \\
{[644]}\end{array}$ & $\begin{array}{c}900 \\
{[840]}\end{array}$ & $\begin{array}{c}1300 \\
{[1039]}\end{array}$ & $\begin{array}{c}17[18] \\
2.7\end{array}$ & $\begin{array}{c}4.8 \\
{[4.9]}\end{array}$ & $\begin{array}{c}3.9 \\
{[4.2]}\end{array}$ & 0.23 & 0.023 & 3.7 & 0.54 & - & $27_{\mathrm{C}}$ & 2056 \\
\hline $\begin{array}{l}\text { Allocyttus verrucosus } \\
\text { Off Tasmania } \\
\text { (Stewart et al. 1995) }\end{array}$ & 1000 & 1200 & 1400 & $11 / 10 / 8.8$ & 4.2 & 3.6 & 0.06 & 0.01 & 12.4 & 1.79 & - & 24 & 102 \\
\hline $\begin{array}{l}\text { Neocyttus rhomboidalis } \\
\text { South East Australia } \\
\text { (Smith \& Stewart 1994) }\end{array}$ & 600 & 700 & 800 & $17 / 15 / 14$ & 5.2 & 7.6 & 0.05 & 0.005 & 8.5 & 0.77 & - & $33_{b}$ & 97 \\
\hline
\end{tabular}




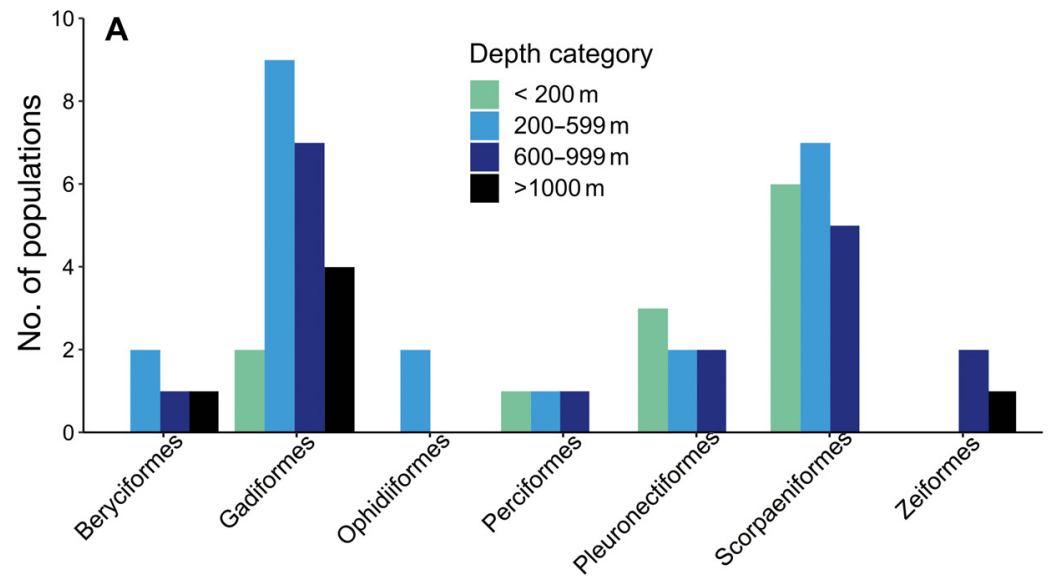

Phylogenetic order

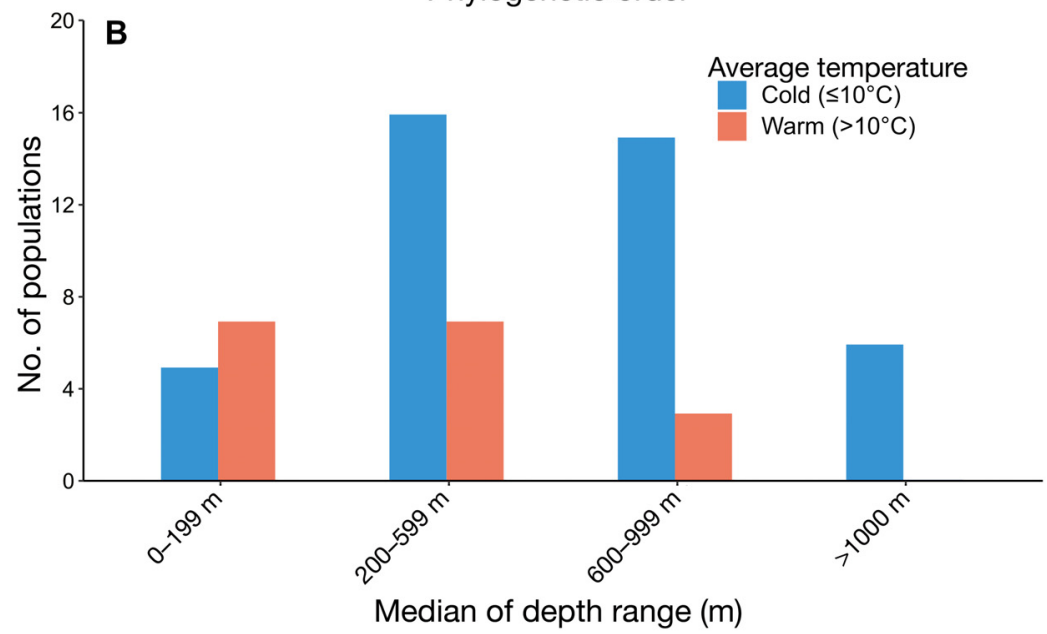

Fig. 1. Numbers of populations of fishes in this study organized by (A) lifespan depth category and (B) average temperature of habitat. Median depths across the entire fish lifespan were used to categorize each species

\subsection{Multivariate GLMM analysis}

The GLMM for prematurity analysis explained more variation in all growth metrics than that for lifespan. Therefore, we report only the prematurity GLMM analysis here. See Figs. S9 \& S11, Tables S7 \& S8 in Supplement 3 for GLMM results upon excluding $C$. armatus. $K$ was best explained by a negative relationship with minimum depth and a positive relationship with temperature $\left(\mathrm{R}^{2}=47 \%, \mathrm{AICC}=-127.9\right.$, hierarchical partitioning: $71 \%$ for depth, $28 \%$ for temperature, predictors removed: NPP; Table 2, Fig. 5). Five additional models were just as likely as the best model by $\triangle \mathrm{AICC}<2$, including some combination of minimum depth, temperature, Lutz POC flux, and locomotory mode (Table 2). The secondbest model indicated that $K$ was nearly just as likely to be explained by depth alone $\left(\mathrm{R}^{2}=45 \%\right.$, AICc $=-127.7$, predictors removed: NPP). Random-effect intercepts for each phylogenetic family all showed overlapping confidence intervals, with sebastids appearing slightly farther from the mean (Fig. S6 in Supplement 3). This is likely due to the large variability of growth rate within the family and the especially slow growth of Sebastolobus alascanus

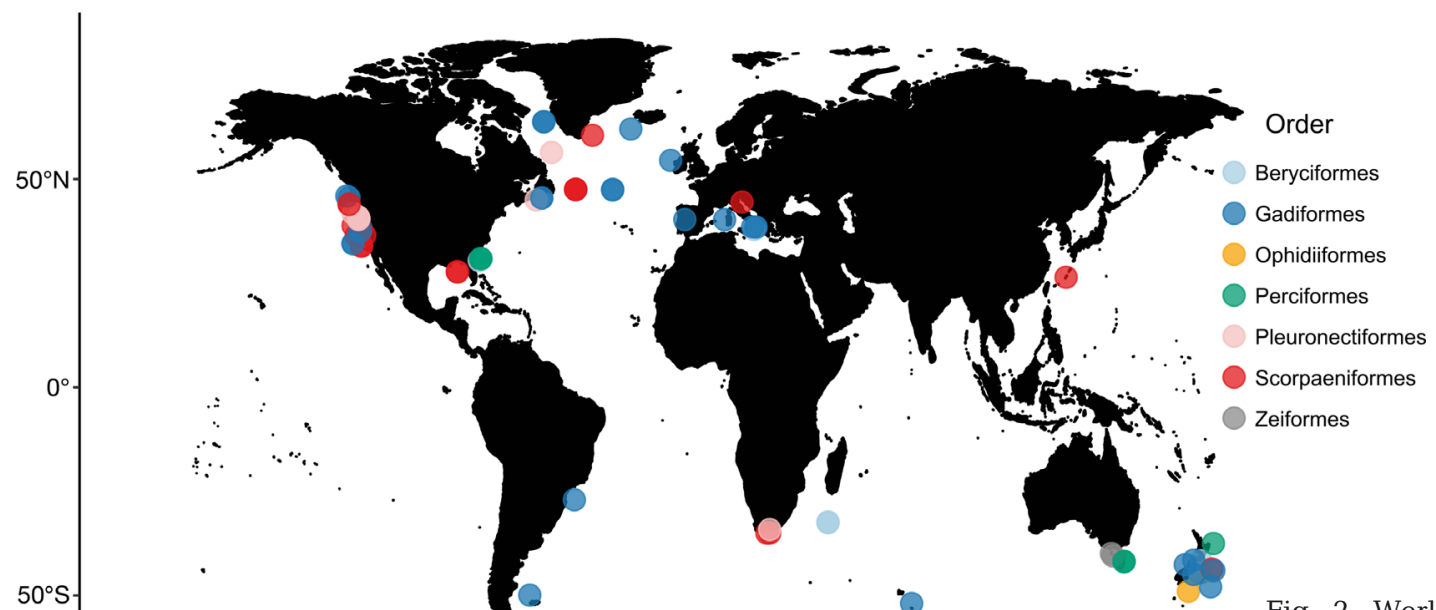

$50^{\circ} \mathrm{s}$

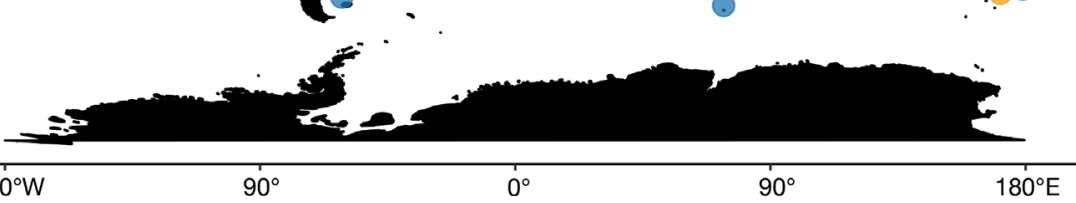

Fig. 2. World map highlighted with catch locations from each study used for the meta-analysis. Catch locations are colored by 


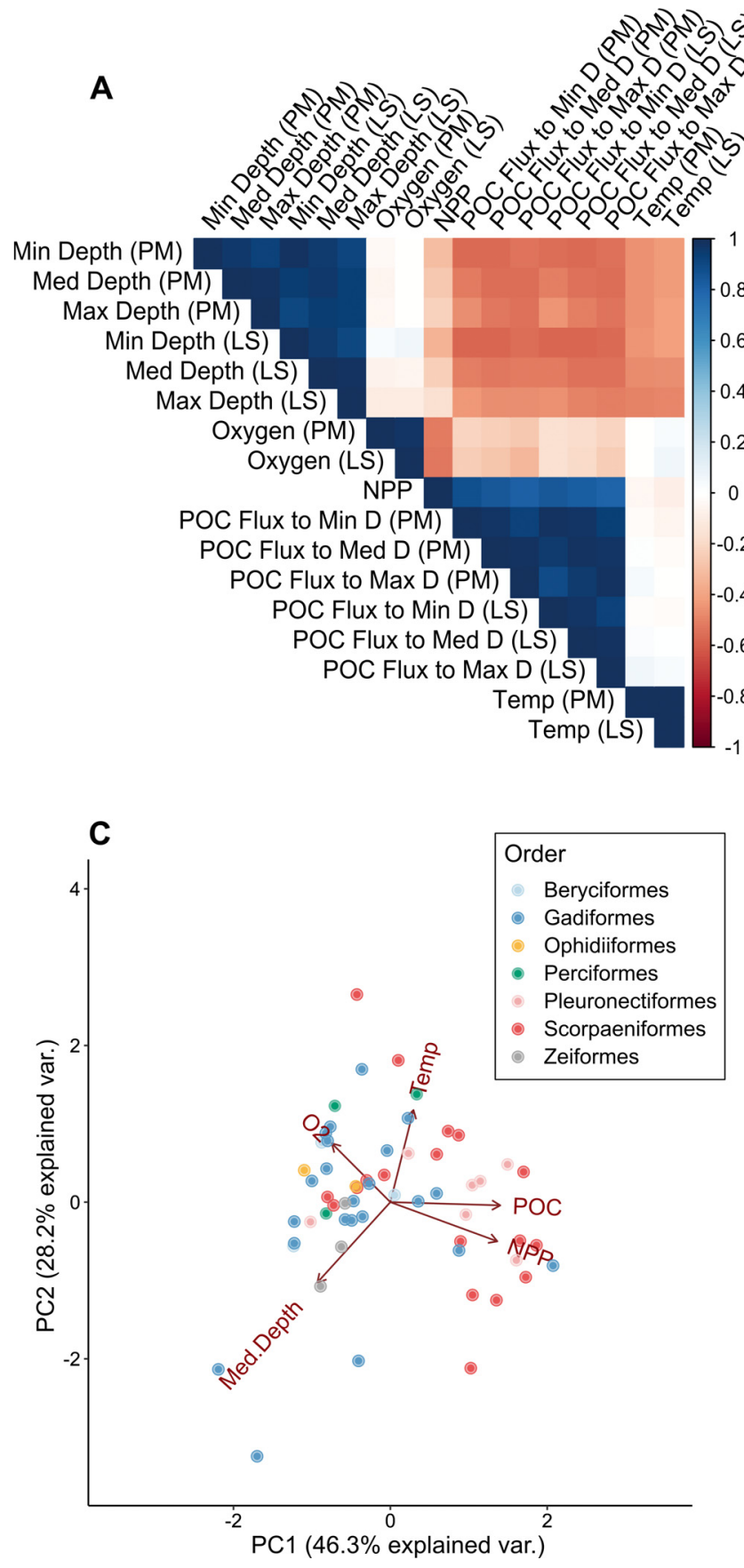

(Figs. S12-S15 in Supplement 3). When a random effect for phylogenetic family was not included, locomotory mode was also included, along with depth and temperature, as an important predictor in the best model, with benthopelagic fishes growing more quickly than benthic fishes (Table S2 in Supplement 3). However, hierarchical partitioning revealed that depth and temperature were by far the primary drivers $\left(\mathrm{R}^{2}=49 \%\right.$, weight $=0.36$, hierarchical partitioning: $64 \%$ for depth, $30 \%$ for temperature, and $6 \%$ for

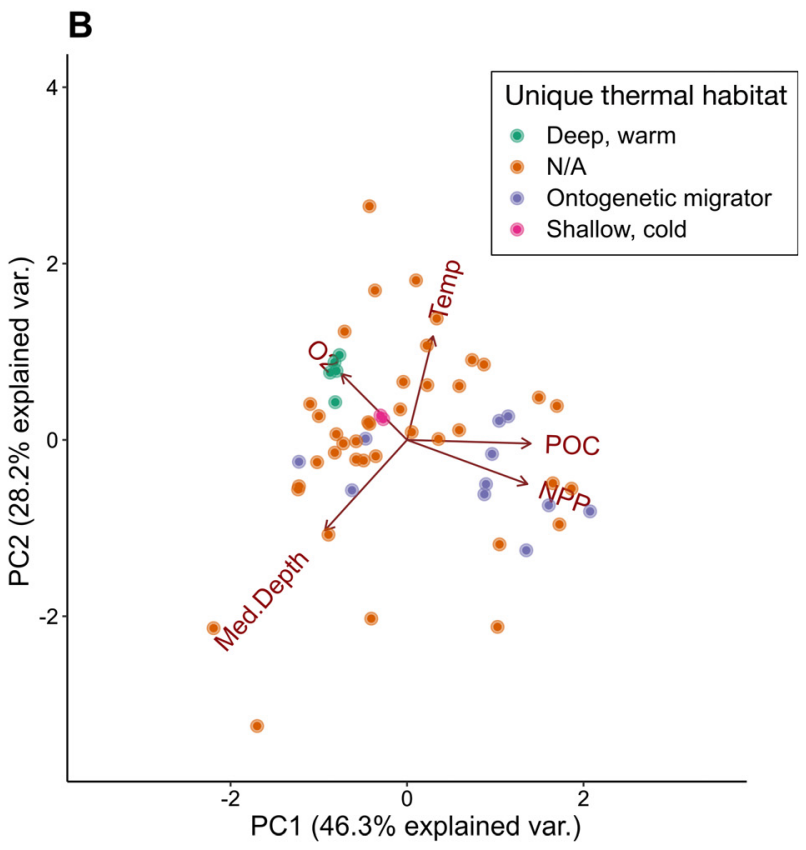

Fig. 3. (A) Correlation plot of all continuous growth predictors used in this meta-analysis. Deeper colors indicate larger magnitudes of the Pearson correlation coefficient. Blue hues: positive correlation; red hues: negative correlation. (B) PCA plots of prematurity predictors. Points are colored by unique thermal habitats (if applicable) that contrast the typical 'colder, deeper' paradigm found in the world oceans (see Section 2.1). (C) PCA plot of prematurity predictors. Points are colored by order

locomotory mode, predictors removed: NPP). Rerunning the best model with the addition of prematurity $\mathrm{CS}_{\mathrm{H}}$ as a predictor increased $\mathrm{R}^{2}$ to $61 \%$ but limited the sample size to 19 and increased the maximum VIF of the predictors to 2.64 .

$K_{\mathrm{GDY}}$ was best explained by minimum depth and locomotory mode, showing declines with depth and in benthic fishes in the GLMM analysis $\left(\mathrm{R}^{2}=27 \%\right.$, AICc $=-399.2$, hierarchical partitioning: $83 \%$ for depth, $17 \%$ for locomotory mode, weight $=0.64$, predictors removed: NPP; Table 3, Fig. 6). Only one additional model was equally likely (i.e. $\triangle \mathrm{AICC}<2$ ), and contained POC flux, minimum depth, and locomotory mode as important predictors $\left(\mathrm{R}^{2}=29 \%, \mathrm{AICc}=\right.$ -398, predictors removed: NPP; Table 3 ). No changes in important predictors chosen occurred when phylogenetic family was not included in the analysis as a random effect. Random-effect intercepts for each phylogenetic family all showed overlapping confidence intervals (Fig. S7 in Supplement 3). Rerunning 


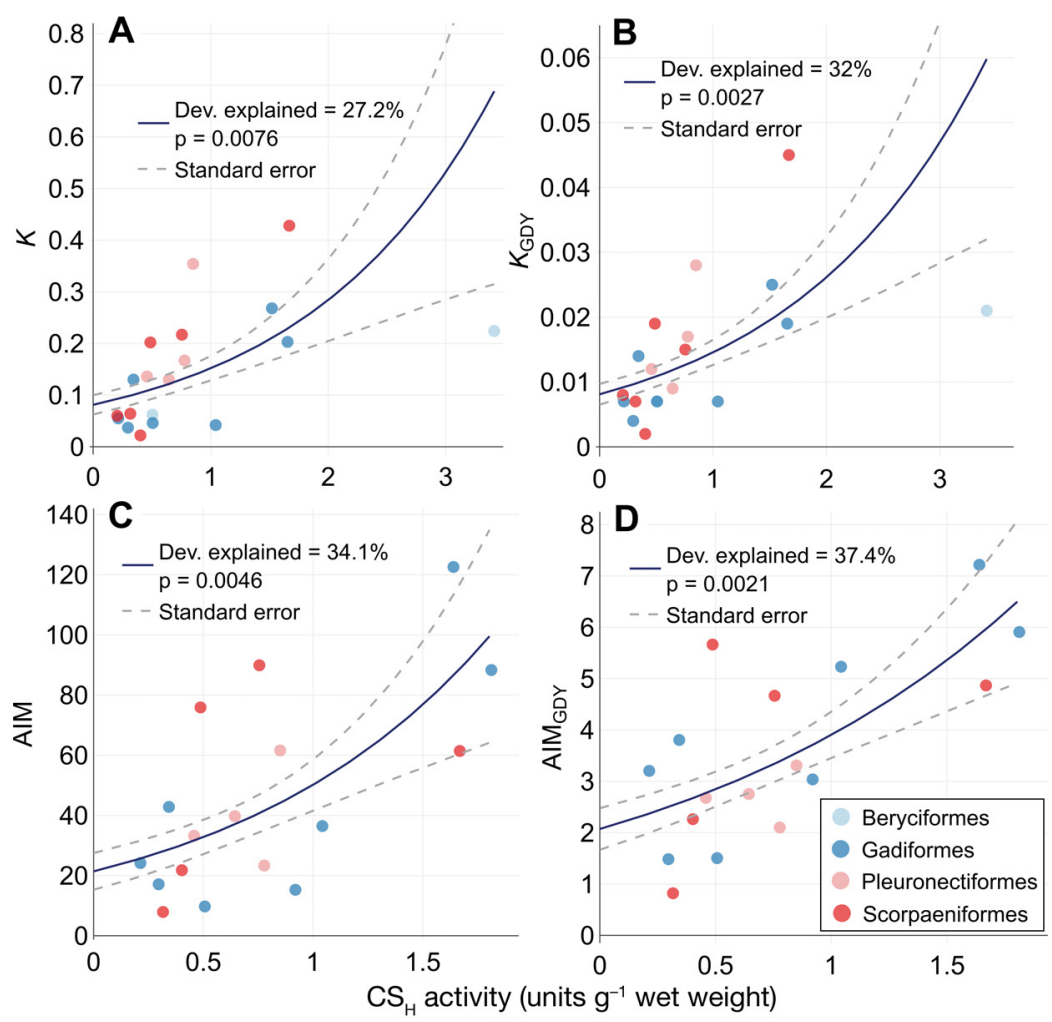

Fig. 4. Growth metrics vs. citrate synthase activity adjusted to average prematurity temperature and normalized to a body mass of $500 \mathrm{~g}$. See 'Adjusted metabolic rates to temperature and mass of habitat' in Supplement 3 for adjustment equations. Blue lines: best-fit regression; grey bands: SE. Top row: values of $K(\mathrm{~A})$ and $K_{\mathrm{GDY}}(\mathrm{B})$ vs. $\mathrm{CS}_{\mathrm{H}}$ activity, colored by order. Bottom row: values of AIM (C) and AIM $_{\mathrm{GDY}}(\mathrm{D})$ vs. $\mathrm{CS}_{\mathrm{H}}$ activity, colored by order and shown without Beryx splendens. Note that the relationships of AIM and $\mathrm{AIM}_{\mathrm{GDY}}$ vs. CS $\mathrm{S}_{\mathrm{H}}$ activity are only significant at the $\mathrm{p}<0.05$ level when $B$. splendens is omitted from the analysis. See Table 1 for definitions of terms

this best model with prematurity $\mathrm{CS}_{\mathrm{H}}$ as a predictor increased $\mathrm{R}^{2}$ to $47 \%$ but limited the sample size to 19 .

AIM was best explained by temperature and depth, but the importance of depth was sensitive to C. armatus inclusion. When $C$. armatus was included, GLMM analysis indicated that variation in AIM is best explained by temperature, Lutz POC flux, and $\mathrm{O}_{2}$, in that rank order $\left(\mathrm{R}^{2}=38 \%\right.$, weight $=$ 0.37, hierarchical partitioning: $49 \%$ for temperature, $39 \%$ for Lutz POC flux, and $12 \%$ for $\mathrm{O}_{2}$, predictors removed: NPP; Table 4, Fig. 7). Three additional models were equally likely by $\Delta \mathrm{AICc}<2$, each containing some combination of POC flux, median depth, $\mathrm{O}_{2}$, and temperature $\left(\mathrm{R}^{2}=32-38 \%\right.$, predictors removed: NPP; Table 4). Random-effect intercepts for each phylogenetic family all showed overlapping confidence intervals (Fig. S8 in Supplement 3). When the random effect for phylogeny was removed, median depth, temperature, and $\mathrm{O}_{2}$ were important predictors of variation in $\mathrm{AIM}\left(\mathrm{R}^{2}=38 \%\right.$, weight $=$
0.34, hierarchical partitioning: $72 \%$ for depth, $20 \%$ for temperature, and $8 \%$ for $\mathrm{O}_{2}$, predictors removed: NPP). There were again 3 additional models with $\triangle \mathrm{AICC}<2$, each containing some combination of these same predictors $\left(\mathrm{R}^{2}=33-40 \%\right.$, predictors removed: NPP; Table S3 in Supplement 3). Rerunning this best model with prematurity $\mathrm{CS}_{\mathrm{H}}$ as a predictor increased $\mathrm{R}^{2}$ slightly to $40 \%$ but limited sample size to 18 , prevented the use of phylogeny as a random effect, and the maximum VIF of the predictors increased to 3.11 .

AIM $_{\mathrm{GDY}}$ declined with decreasing $\mathrm{O}_{2}$, increasing depth, and in benthic fishes, but results are sensitive to $C$. armatus inclusion. When $C$. armatus was included in the analysis, AIM $_{\mathrm{GDY}}$ was found to be best explained by $\mathrm{O}_{2}$ and Lutz POC flux $\left(\mathrm{R}^{2}=22 \%, \mathrm{AICC}=\right.$ 73.3, weight $=0.40$, hierarchical partitioning: $80 \%$ for $\mathrm{O}_{2}, 20 \%$ for Lutz POC flux, predictors removed: NPP; Table 5, Fig. 8). Two additional models were equally likely by $\Delta \mathrm{AICC}<2$ : one model containing $\mathrm{O}_{2}$ alone $\left(\mathrm{R}^{2}=\right.$ $18 \%, \mathrm{AICc}=73.3$, weight $=0.40$; Table 5) and another model containing $\mathrm{O}_{2}$, locomotory mode, and Lutz POC flux $\left(\mathrm{R}^{2}=24 \%, \mathrm{AICc}=74.7\right.$, weight $=0.20$; Table 5). Randomeffect intercepts for each phylogenetic family all showed overlapping confidence intervals, but there are a few apparent outliers in the model residuals (Fig. S10 in Supplement 3). When random effects were excluded, these patterns were similar, but with a drop in $\mathrm{R}^{2}$ for one of the 3 output models $\left(\mathrm{R}^{2}=\right.$ 13-20\%; Table S6 in Supplement 3). Rerunning this best model with prematurity $\mathrm{CS}_{\mathrm{H}}$ as a predictor increased $\mathrm{R}^{2}$ to $32 \%$ but limited sample size to 18 .

\section{DISCUSSION}

This study presents the first comprehensive examination of the environmental and physiological drivers of demersal fish growth rates across the depth continuum. The general decline in the von Bertalanffy growth coefficient $K$ with depth observed by Drazen \& Haedrich (2012) was found again here (Fig. 5). Prematurity depths for ontoge- 
Table 2. Results of dredge analysis of $K$ vs. prematurity predictors with phylogenetic family as a random effect, showing models with a $\triangle$ AICc score of $<2$ relative to the top model. For numerical predictors, the intercept (Int.) is shown if the predictor is in the model. A ' + ' is shown if locomotory (Loc.) mode is included. Global model call: glmer(formula $=\mathrm{K} \sim$ scale $($ min depth $)+$ scale $($ Lutz POC flux to max depth $)+$ scale $(O 2)$ + locomotory mode $+(1$ | phyl. family $)$, data $=$ meta.sub, family $=$ Gamma na.action $=$ 'na.fail'). Predictors removed: NPP

\begin{tabular}{|lcccccccccc|}
\hline Models & Int. & $\begin{array}{c}\text { Loc. } \\
\text { Mode }\end{array}$ & $\begin{array}{c}\text { Min. } \\
\text { Depth }\end{array}$ & $\begin{array}{c}\text { Lutz } \\
\text { POC flux }\end{array}$ & Temp. & $\mathrm{R}^{2}$ & AICc & AICc Weight \\
\hline 1 & 7.02 & & 3.345 & & -0.6743 & 0.472 & -127.9 & 0 & 0.205 \\
2 & 6.846 & & 3.881 & & & 0.4461 & -127.7 & 0.26 & 0.18 \\
3 & 8.049 & + & 3.61 & & -0.7151 & 0.4916 & -127.5 & 0.4 & 0.168 \\
4 & 8.149 & + & 2.835 & -0.7975 & -1.027 & 0.5144 & -127.5 & 0.45 & 0.164 \\
5 & 6.977 & & 2.641 & -0.7279 & -0.9488 & 0.49 & -127.3 & 0.57 & 0.154 \\
6 & 7.825 & + & 4.144 & & & 0.4631 & -127 & 0.93 & 0.129 \\
\hline
\end{tabular}

cause depth is not a direct ecological driver, and there is still considerable variation in growth ( 60-90\%, depending on the metric) that is unexplained by depth alone (Table S1 in Supplement 3).

Temperature during the prematurity phase was found to be an important predictor of $K$ and AIM (Table S1 in Supplement 3, Figs. $5 \& 7$ ). Our findings reinforce the exponential increases in interspecific growth rate as a function of temperature hypothesized in prior work (Van der

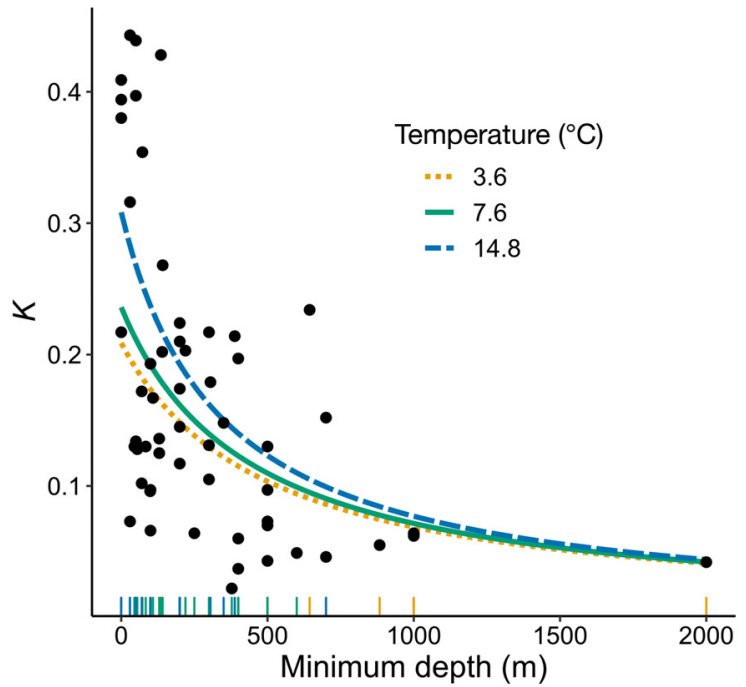

Fig. 5. Effects of the top mixed model of $K$ vs. minimum depth when temperature is held at the median (green, dashed line), first quartile (yellow, dotted line), and third quartile (blue, dashed line). Rug values for each data point are colored according to closest proximity to median, first quartile, or third quartile

netic migrators explained more variation in $K$ and $K_{\mathrm{GDY}}$ than when lifespan-averaged depths were used (Table S1 in Supplement 3). This is not surprising, given that most fish growth occurs in the prematurity phase of life and thus habitat variables must be matched accordingly. Average percent increase in mass during the prematurity phase (i.e. AIM) also declined with depth, though this was sensitive to the inclusion of Coryphaenoides armatus (Table S1 in Supplement 3, Fig. 7). However, observing the depth pattern alone does not lead to an understanding of the underlying drivers be-
Have \& De Jong 1996, Jobling 1997, Neuheimer \& Grønkjær 2012, Rall et al. 2012). It should be noted that the patterns with temperature in this interspecific meta-analysis do not reflect those found in intraspecific studies. While populations of a given species in warmer temperatures have been shown to grow faster than conspecifics inhabiting colder temperatures, this intraspecific growth response is unimodal: growth rate initially increases with temperature to an optimum and decreases beyond this threshold (Braaten \& Guy 2002, Pörtner \& Knust 2007, Thresher et al. 2007, Neuheimer et al. 2011, Rypel 2012). A similar meta-analysis of growth in freshwater fishes across South America by de Santana et al. (2020) primarily focused on the effects of latitude as a proxy for temperature but did not find a significant relationship with interspecific growth rate, although they found that intraspecific asymptotic length decreases with latitude. Their meta-analysis differed in that it focused on freshwater habitat, used latitude as a proxy for temperature (which is imprecise), and incorporated ageing methods not included here (scales, vertebrae, length-frequency analysis, etc.).

Contrary to expectations, the apparent influence of depth was still present even after the signal of temperature was accounted for with temperatureadjusted growth rates. Multivariate mixed models showed that $26 \%$ of the remaining variability in $K_{\mathrm{GDY}}$ is explained by depth and locomotory mode. This would suggest that temperature is not the sole driver of variation in $K$ across depth. Compared to patterns seen with $K_{\mathrm{GDY}}$, depth was found to be a lesser, but still important, predictor of variation in $\mathrm{AIM}_{\mathrm{GDY}}$, though only upon exclusion of $C$. armatus from the data set. The sensitivity of these patterns in AIM and $\mathrm{AIM}_{\mathrm{GDY}}$ to inclusion of $C$. armatus likely reflects inherent uncertainty as to this species' age-at-matu- 
Table 3. Results of dredge analysis of $K_{\mathrm{GDY}}$ vs. prematurity predictors with phylogenetic family as a random effect, showing models with a $\Delta$ AICc score of $<2$ relative to the top model. For numerical predictors, the intercept (Int.) is shown if the predictor is in the model. A ' + ' is shown if locomotory (Loc.) mode is included. Global model call: glmer(formula $=K_{\mathrm{GDY}} \sim \operatorname{scale}(\min$ depth $)+$ scale $($ Lutz POC flux to mid depth $)+$ scale $\left(\mathrm{O}_{2}\right)+$ locomotory mode $+(1$ । phyl. family $)$, family $=$ Gamma, na.action $=$ 'na.fail'). Predictors removed: NPP

\begin{tabular}{|lcccccccc|}
\hline Models & Int. & $\begin{array}{c}\text { Loc. } \\
\text { Mode }\end{array}$ & $\begin{array}{c}\text { Min. } \\
\text { Depth }\end{array}$ & $\begin{array}{c}\text { Lutz } \\
\text { POC flux }\end{array}$ & $\mathrm{R}^{2}$ & AICc & $\Delta$ AICc & Weight \\
\hline 1 & 92.19 & + & 26.97 & & 0.2732 & -399.2 & 0 & 0.644 \\
2 & 92.23 & + & 22.82 & -5.888 & 0.2902 & -398 & 1.19 & 0.356 \\
\hline
\end{tabular}

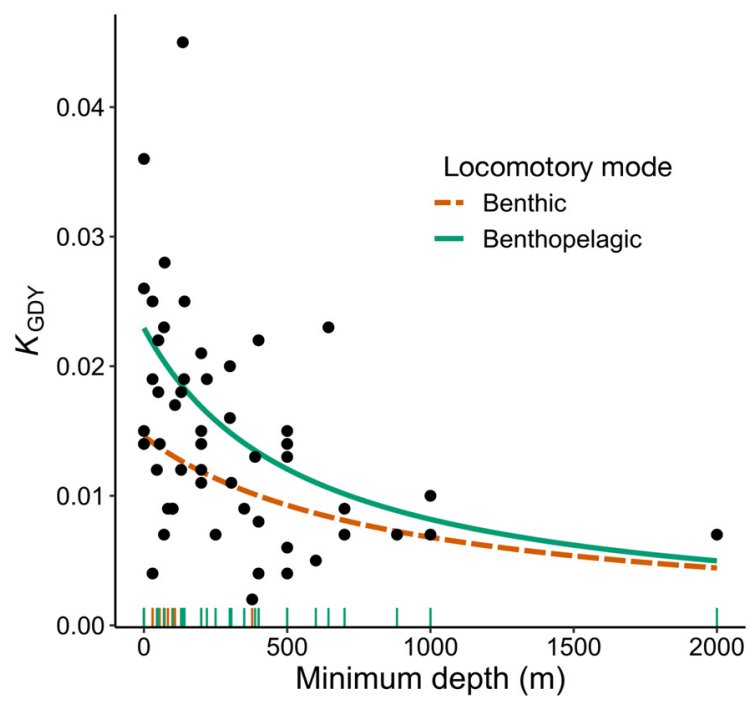

Fig. 6. Effects of top mixed model of $K_{\mathrm{GDY}}$ vs. minimum depth for benthic (orange, dashed line) and benthopelagic (green, solid line) fishes. Rug values for each data point are colored according to locomotory mode

rity, as well as a lack of data for other abyssal species, which is discussed in more detail below. Nevertheless, the persistent significance of depth in explaining $K_{\mathrm{GDY}}$ and $\mathrm{AIM}_{\mathrm{GDY}}$ suggests the influence of additional variables associated with depth in determining growth.

The estimates of food availability used here were not found to be important predictors of interspecific growth rates (Table 2). Lutz POC flux was a secondary predictor of AIM and AIM $_{\mathrm{GDY}}$, but only when the outlier C. armatus was included. These results echo the findings of the meta-analysis by McClain et al. (2012) in which the amount of chemical energy present in the base of the food web was not found to control interspecific patterns in rockfish growth rates, but instead constrains population- or ecosystem-level processes such as abundance, biodiversity, and total biomass. Indeed, fisheries research has found that wild populations increase in abundance until reaching a carrying capacity determined at least in part by availability of prey (reviewed in Anderson 1988 and Le Pape \& Bonhommeau 2015). Population sizes of abyssal fishes are thought to track long-term fluctuations in prey abundance, with interannual changes in population densities likely due to migration rather than increased reproduction rates (Drazen et al. 2012, Milligan et al. 2020). Studies on the energetics of individual growth in fishes have established that an increase in food ration leads to more rapid growth, and intraspecific variation in growth rates on short timescales, such as in aquaculture settings, clearly affects fish growth rates (Persson \& De Roos 2006). Despite food's importance as an intraspecific driver of individual growth in aquaculture settings, it appears that interspecific patterns in growth across depth are relatively unaffected by variability in food supply as measured via Lutz POC, NPP, or SCOC. However, we were unable to incorporate these 2 predictors into GLMM analysis due to covariation and lack of data, respectively. It is possible, given more data on SCOC rates or other food supply metrics, that a significant relationship with growth would be apparent.

Oxygen was found to be an important predictor of AIM, though relatively less so than depth and temperature. In GLMM analyses, $\mathrm{O}_{2}$ only explained about $5 \%$ of variation in AIM. After correcting for temperature, the influence of $\mathrm{O}_{2}$ was much stronger, becoming the most important predictor of $\mathrm{AIM}_{\mathrm{GDY}}$ with or without the inclusion of $C$. armatus. However, this pattern with AIM $_{\mathrm{GDY}}$ was driven by several oxygen minimum zone (OMZ)-dwelling fishes inhabiting $\mathrm{O}_{2}$ concentrations of less than $2 \mathrm{ml} \mathrm{l}^{-1}$. Oxygen has been linked with growth in the literature: overall population biomass, maximum body size, and abundance tends to correlate with oxygen levels within OMZs (reviewed in Gallo \& Levin 2016). Intraspecific studies have shown a link between metabolism, oxygen concentration, and growth, with hypoxic conditions suppressing growth and metabolic rate in actively swimming fishes, though the critical concentration at which suppression occurs is speciesspecific (reviewed in Gray et al. 2002). Moreover, the heightened longevity observed in deeper dwelling fishes has been attributed to lower concentrations of 
Table 4. Results of dredge analysis of AIM vs. prematurity predictors including Coryphaenoides armatus and with phylogenetic family as a random effect, showing models with a $\triangle$ AICc score of $<2$ relative to the top model. For numerical predictors, the intercept (Int.) is shown if the predictor is in the model. Global model call: glmer(formula $=$ AIM $\sim$ scale $($ med. depth $)+$ scale $($ Lutz POC flux to max depth $)+\operatorname{scale}\left(\mathrm{O}_{2}\right)+$ scale $($ temperature $)+$ locomotory mode $+(1$ I phyl. family $)$, family = Gamma, na.action $=$ 'na.fail'). Predictors removed: NPP

\begin{tabular}{|lccccccccc|}
\hline Models & Int. & $\begin{array}{c}\text { Loc. } \\
\text { Mode }\end{array}$ & $\begin{array}{c}\text { Min. } \\
\text { Depth }\end{array}$ & $\begin{array}{c}\text { Lutz } \\
\text { POC flux }\end{array}$ & Temp & $\mathrm{R}^{2}$ & AICc & AICc Weight \\
\hline 1 & 1.361 & & -0.3944 & -0.3187 & -0.3689 & 0.3799 & 81.2 & 0 & 0.367 \\
2 & 1.337 & 0.5791 & -0.2696 & & -0.1653 & 0.3687 & 82.1 & 0.87 & 0.237 \\
3 & 1.377 & 0.3014 & -0.3561 & -0.2198 & -0.2738 & 0.4012 & 82.2 & 1.02 & 0.22 \\
4 & 1.292 & 0.7638 & -0.2156 & & & 0.3261 & 82.7 & 1.47 & 0.176 \\
\hline
\end{tabular}

oxygen and thus free radical damage to cells, though high longevity is not necessarily coupled to growth rate (Cailliet et al. 2001). Generally, less is known regarding the effects of oxygen on interspecific growth rates. High $\mathrm{O}_{2}$ demand has been associated with rapidly growing, 'high performance' fishes such as tuna and mahi mahi (Brill 1996). However, prior work on demersal species has not shown a clear pattern between environmental $\mathrm{O}_{2}$ concentration and rate of metabolism. Rather, a strong positive correlation between high metabolism and mass-specific gill surface area has been found (Friedman et al. 2012), and deep-sea species appear to have scaling exponents of metabolic rate that indicate they are less limited by the geometric constraints of oxygen transport than shallower fish (Killen et al. 2010). Our analysis shows that sablefish live at low concentrations of oxygen $\left(\sim 0.7-2.7 \mathrm{ml} \mathrm{l}^{-1}\right)$ and have high rates of metabolism and growth, but also were found by Friedman et al. (2012) to have relatively higher gill surface area than several of the slow-growing OMZ-dwellers in our data set, such as Sebastolobus alascanus, S. altivelis, and Microstomus pacificus. The positive relationship between growth and $\mathrm{O}_{2}$ we found was driven entirely by these slow-growing OMZdwellers, which may indicate a threshold response in that oxygen only limits maximum growth rate at concentrations lower than about $2 \mathrm{ml} \mathrm{l}^{-1}$, and only in fishes without specific adaptations for high gill surface area.

The influence of phylogeny on growth appears to be minor, though we were unable to conclusively and quantitatively determine its effect on growth. Across phylogenetic orders, no significant differences were found in $K$ or $K_{\mathrm{GDY}}$. Only Zeiformes (the oreos) were found to grow significantly slower than other orders in

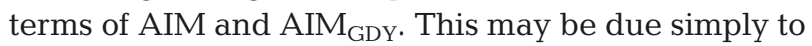
a lack of sampling in this order because all 3 species analyzed are deep living, with median lifespan
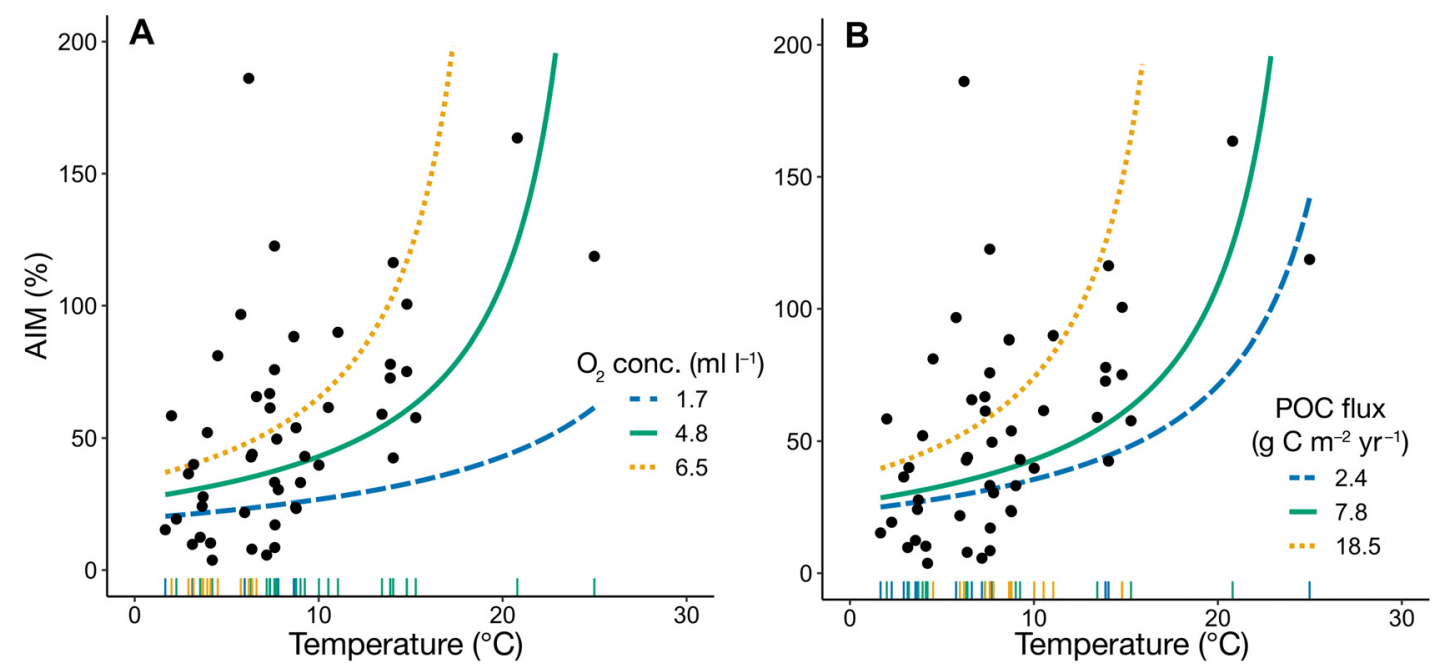

Fig. 7. (A) Effects of the top mixed model of AIM vs. temperature when oxygen is held constant at the median (green, solid line), first quartile (blue, dashed line), and third quartile (yellow, dotted line) values. Particulate organic carbon (POC) flux is held constant at the median value. (B) Effects of the top mixed model of AIM vs. temperature when POC flux is held constant at the median (green, solid line), first quartile (blue, dashed line), and third quartile (yellow, dotted line) values, and oxygen concentration is held constant at the median value $\left(4.8 \mathrm{ml} \mathrm{l}^{-1}\right)$. Rug values for each data point are colored according to closest proximity to median, first quartile, or third quartile 
Table 5. Results of dredge analysis of $\mathrm{AIM}_{\mathrm{GDY}}$ vs. prematurity predictors with phylogenetic family as a random effect when Coryphaenoides armatus is included. Only models with a $\triangle \mathrm{AICc}$ score of $<2$ relative to the top model are shown. For numerical predictors, the intercept (Int.) is shown if the predictor is in the model. A ' + ' is shown if locomotory (Loc.) mode is included. Global model call: glmer(formula = AIM scale(med. depth) + scale(Lutz POC flux to max depth) + scale $\left(\mathrm{O}_{2}\right)+$ locomotory mode $+(1$ । phyl. family $)$, data $=$ meta.sub, family $=$ Gamma, na.action = 'na.fail' $)$. Predictors removed: NPP

\begin{tabular}{|lcccccccc|}
\hline Models & Int. & $\begin{array}{c}\text { Loc. } \\
\text { Mode }\end{array}$ & $\begin{array}{c}\text { Min. } \\
\text { Depth }\end{array}$ & $\begin{array}{c}\text { Lutz } \\
\text { POC flux }\end{array}$ & $\mathrm{R}^{2}$ & AICc & $\Delta$ AICc Weight \\
\hline 1 & 1.176 & & -0.2506 & -0.1428 & 0.217 & 73.3 & 0 & 0.401 \\
2 & 1.204 & & -0.2006 & & 0.176 & 73.3 & 0.02 & 0.398 \\
3 & 1.343 & + & -0.2493 & -0.1635 & 0.2362 & 74.7 & 1.39 & 0.201 \\
\hline
\end{tabular}

Froese 2013). We also included the shallow dwelling ophidiid Genypterus blacodes but were unable to find age and growth data for deep-sea members of this family. Similar meta-analyses on chondrichthyan growth rates have investigated the importance of phylogeny as a predictor: García et al. (2008) found correlations with growth rates and genus, and Rigby \& Simpfendorfer (2015) found that after accounting for phylogeny, the influence of environmental conditions on

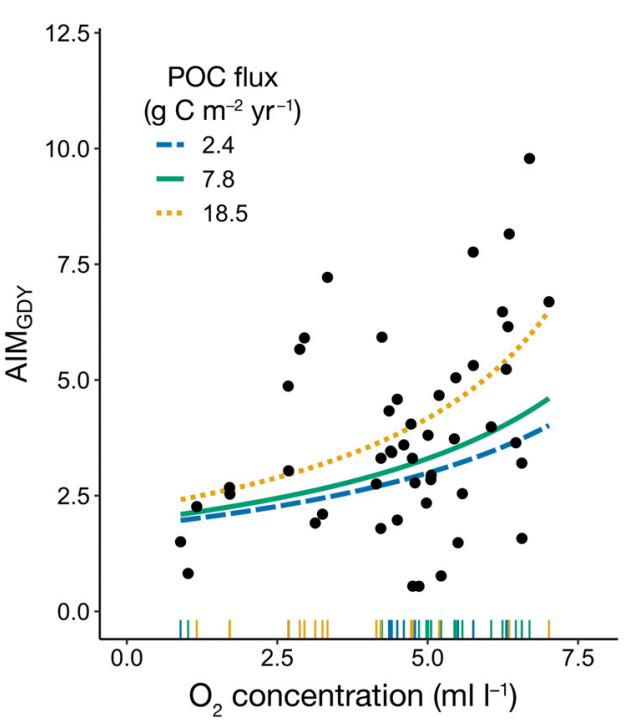

Fig. 8. Effects of the top mixed model of $\mathrm{AIM}_{\mathrm{GDY}}$ vs. oxygen concentration when particulate organic carbon (POC) flux is held constant at the median (green, solid line), first quartile (blue, dashed line), and third quartile (yellow, dotted line) values. Rug values for each data point are colored according to closest proximity to median, first quartile, or third quartile

depths $>600 \mathrm{~m}$. We had insufficient data to correct for variability in responses to our environmental variables at the species level using random effects but were able do so at the family level. Important predictors of variation in AIM change when phylogeny is incorporated as a random effect (see results for GLMM analysis and Tables S4 \& S5 in Supplement 3), but these are small shifts from one covarying factor to another (e.g. Lutz POC flux vs. depth). The effect of phylogeny is difficult to address, particularly because growth data are not available for shallow-water members of some deep-sea families, such as the Oreosomatidae and Macrouridae (Drazen \& Haedrich 2012, Priede \& growth was still significant. Overall, the effect of phylogeny is inconclusive, but its incorporation into these analyses as a random effect appears to account for some underlying variation in growth. Our findings reinforce those of Rigby \& Simpfendorfer (2015), that while phylogeny can be important, other environmental drivers seem to be more so.

Temperature and depth fall out from our analyses as the primary, indirect drivers of growth, and in addition we found a strong positive relationship to metabolic rate, though it is not clear whether it is a driver or covarying energetic parameter across the depth continuum. All 3 CS activity predictors - nonadjusted, adjusted to average temperature, and adjusted to average prematurity temperature-were found to be significantly related to nearly all the growth metrics in this study (Fig. 4). While there was insufficient data to include metabolic rate as a predictor in the full mixed-model analysis, adding it to the top mixed model for each growth metric drastically increased the variation explained. Metabolic rate in demersal fishes has been found to decline with depth even after accounting for temperature and body size effects (Sullivan \& Somero 1980, Drazen \& Seibel 2007, Drazen et al. 2015). It is yet unclear whether the depth-related decline in metabolic rate is mechanistically driving the patterns observed in growth rate or simply correlates to decreased maintenance costs and activity levels associated with increasing depth (Killen et al. 2010). Careau et al. (2008) suggest 2 possible models for energy budgeting of growth and metabolism. In the allocation model, metabolic rate reflects the baseline energetic cost of cellular maintenance, and leftover energy is funneled into activity and/or growth (i.e. growth rate can be negatively correlated with metabolism). In the performance model, the metabolic rate represents the mechanistic rates of biochemical processes 
including channeling of energy into growth, resulting in positive correlations between growth and metabolic rates. Both models have found some support in intraspecific studies, with relationships between growth and metabolic rate changing across low, intermediate, and ad libitum food levels (Careau et al. 2008, Jobling 2010, Killen 2014, Auer et al. 2015). Our findings of positive correlations between growth and metabolic rates generally support the performance model. Our findings also align with a broad pattern of 'fast vs. slow' life history adaptations observed across and within animal taxa. That is, variation in life history parameters can be partly explained by a fast vs. slow dichotomy, with organisms with a relatively faster pace of life having more proactive behavior, short times-to-maturity, higher activity levels, shorter lifespan, and more rapid growth than 'slower' organisms. (Mittelbach et al. 2014, Auer et al. 2018, Damsgård et al. 2019; reviewed in Réale et al. 2010).

Ultimately, the question is what evolutionary pressure is driving slow growth and slow metabolic rates in deep-sea fishes? Studies on catch-up growth in teleosts have demonstrated that these organisms typically grow at sub-maximal rates, but grow faster upon feeding after a period of starvation, to the detriment of their tissue quality and overall lifespan (Metcalfe et al. 2002, Alvarez \& Metcalfe 2005, Jobling 2010, Hector \& Nakagawa 2012). Taken together, these patterns would suggest that growth rate is not strictly bound to metabolic rate as a function of temperature and body mass, but rather the deep sea broadly selects for slower paces of life, typically low growth and metabolic rates and long lifespans and maturation times. Within the physiological constraints on growth rate imposed by environmental conditions, the remaining variation in growth rate is likely driven by the evolutionary fitness conferred by slower rates in deeper environments. The visual interactions hypothesis has suggested that high metabolic rates (and thus high locomotory capacity and response rate) are relatively advantageous in shallower, more illuminated habitats to facilitate prey pursuit and predator avoidance over larger distances (Childress 1995). As light decreases with depth to $\sim 1000 \mathrm{~m}$, the accompanying decrease in escape distances, visual detection range, and overall predator and prey densities favors a slower metabolic rate and perhaps a suite of life history strategies including slow growth and reactive rather than proactive behavior. Predation risk from marine mammals also drops sharply with depth (though some marine mammals forage deeper than $1000 \mathrm{~m}$ ), which might result in lower mortality risk and relaxing selective pressure for both fast growth/early maturity and highperformance swimming ability in prey fishes. The importance of locomotory mode as an important predictor of growth in some of our models may also reflect the fast vs. slow dichotomy of life history strategies (Réale et al. 2010), as we found the lower activity benthic species to grow slightly slower than more active benthopelagics. Interestingly, Beryx splendens, a deep seamount dweller with rapid metabolism, high activity, but a very slow growth rate, was an exception to our overall findings. This result matches earlier work suggesting that high metabolic rate but slow growth might be common in seamount fishes (Koslow 1996). In this case, it is possible that the seamount ecosystem, which is more swept by currents and attracts large numbers of predators (Morato et al. 2010) in relation to many other deep habitats, favors higher swimming and metabolic activity (Koslow 1996), but why this then favors slower growth (given the potentially higher predation risk) is unclear. Further, Hoplostethus atlanticus, another seamount species in our data set, had low growth but did not have a high metabolic rate. We suggest that further expanding both metabolic and growth rate measurements on seamount-associated fishes may be a way to more clearly identify evolutionary pressures on energetic parameters in deep-sea fishes.

The strong relationships found in this meta-analysis provide an essential first step in understanding the drivers of growth variation and in locating gaps in the current knowledge for targeted research. However, a fully predictive model of growth across the depth continuum or a complete mechanistic understanding of its drivers will require much more data, a greater understanding of evolutionary pressures on deep-sea life histories, and better estimates of food availability. The potential explanatory power of metabolic rate in our data set, though limited by sample size, is a promising step in a fully predictive framework. Adding metabolic rate data to the top mixed model increased $\mathrm{R}^{2}$ values from $47-61 \%$ when explaining $K$, and from $27-47 \%$ in explaining $K_{\mathrm{GDY}} \cdot \mathrm{R}^{2}$ values for explaining $\mathrm{AIM}$ and $\mathrm{AIM}_{\mathrm{GDY}}$ also increased drastically when metabolic rate data was added (38-67\% for AIM, $22-61 \%$ for $\mathrm{AIM}_{\mathrm{GDY}}$ B B. splendens omitted). This would suggest that while our models are not yet fully predictive due to a limited data set, given sufficient environmental, phylogenetic, and metabolic rate data, a predictive framework for the growth of deepsea demersal fishes is plausible.

Hydrostatic pressure is nearly perfectly correlated with depth and is a variable not directly explored in this analysis. Changes in pressure are known to af- 
fect cell membrane fluidity, enzyme function, and rates of biochemical reactions in fish, and deep-sea fishes possess specific adaptations to tolerate high pressures, such as increased proportions of unsaturated fatty acids in cell membranes, pressureadapted enzymes, and high concentrations of intracellular enzyme-stabilizing piezolytes (Somero 1990, Yancey \& Siebenaller 2015, Gerringer et al. 2017). These adaptations, while necessary for tolerating high pressures, have been found to decrease enzyme efficiency and/or incur associated energetic costs. For example, fishes living below 500 m possess versions of dehydrogenases with reduced pressure sensitivity, but at the cost of catalytic efficiency (Somero 1990). Catalytic efficiency can be increased by simply producing higher concentrations of enzyme, but this increased production requires energetic input. As growth rate is the summed product of rates of many metabolic reactions, some of the explanatory power of depth we observed in predicting growth rates may arise mechanistically from increasing energetic costs associated with maintaining enzyme function and catalytic efficiency with increasing pressure at depth.

It is also worth noting that this work focused on demersal fishes, a group on which most marine growth studies have focused due to their wide commercial exploitation relative to deep pelagic species. In the pelagic, there is less research relating growth rates and depth, though Childress et al. (1980) found that $K$ values generally followed a 'slower, deeper' trend. However, bathypelagic fishes grew faster than shallower mesopelagics in terms of yearly increases in caloric content. That study compared only 10 species and estimated age with whole otoliths, which have been shown to underestimate age particularly in deep-sea species, potentially obfuscating patterns of growth (Campana 2001). However, many of the species analyzed by Childress et al. (1980) have small otoliths, which makes more accurate aging methods such as transverse sectioning less feasible. Regardless, further growth studies on open-ocean fishes are necessary to determine whether they follow similar rates of decline in growth rate with depth as demersal fishes.

A number of past studies could not be included here due to procedural issues and lack of age-validation approaches, which hampered the present analysis. For instance, further work is needed to untangle some of the covariation in depth and temperature by collecting a data set with as many species as possible from the Mediterranean region, where temperature remains constant and relatively warm with depth.
Twenty sources of age and size data from Mediterranean populations were examined, but $75 \%$ used whole otoliths without validation for age estimation and were rejected for quality control reasons (see 'Supplementary Methods' in Supplement 3). It is possible that annuli counts from viewing whole otoliths indeed accurately reflect the age for some or even all of these species, but without radiometric or other independent validation of the ring periodicity, the risk of underestimating age and overestimating growth rate was concern enough to exclude these studies (Campana 2001). More studies of otolith sections or using age validation are needed from warm deep-sea regions. We also acknowledge that the shallow-water growth literature is much broader than synthesized here. We attempted to include as much data as possible that fit quality controls and we focused primarily on including data from phylogenetic families that had representatives from across the depth gradient.

Determining the drivers of growth across demersal fishes is one component of understanding their resiliency to anthropogenic impacts, which continue to expand in the deep sea. Historically, studies of the life histories of deep-sea fish focused on direct exploitation, with some evidence that faster-growing stocks are more resilient to fishing mortality, though this trend is highly dependent on how 'fishing mortality' is defined (Koslow et al. 2000, Bailey et al. 2009, JuanJordá et al. 2015, Pinsky \& Byler 2015, Färber et al. 2020). Past age and growth studies have focused on the upper bathyal $(<1500 \mathrm{~m})$, where commercially harvested species live. However, future threats to the ocean from deep-sea mining (reviewed in Glover \& Smith 2003) and climate change (Sweetman et al. 2017) will occur at greater depths and present a real need for more information. For example, deep-sea mining is likely to commence at an industrial scale within the next few decades, with potentially decadalscale disruptions to both benthic and pelagic habitats (Stratmann et al. 2018, reviewed in Glover \& Smith 2003). Though the spatial and temporal extent of disruption is not yet fully clear, at current proposed depths of operation on seamounts and/or abyssal plains, it would certainly affect some of the deepest, slowest growing species in our analyses (C. armatus, Antimora rostrata, $H$. atlanticus, etc.). In terms of broad-scale anthropogenic climate change, recent estimates suggest abyssal ocean temperature may increase by $1^{\circ} \mathrm{C}$ by the end of the century, with concurrent decreases in the flux of POC (Sweetman et al. 2017). Deep-dwelling Antarctic fishes have no cooler refuge from warming waters, and may be at highest 
risk. As such, we require more growth and life history data from the lower bathyal, abyssal, and hadal zones to fully understand drivers of growth across the full depth gradient and inform assessments of susceptibility to changing habitat conditions.

Deep-sea demersal fishes fulfill critical ecological roles as mid-to-top level predators and may be responsible for direct delivery of carbon from the mesopelagic to the seafloor via consumption of vertical migrators (Trueman et al. 2014, Drazen \& Sutton 2017). These fishes may represent an important component of biogeochemical cycling through deep carbon deposition and burial. It is therefore essential to establish a fully predictive framework with which to gauge the susceptibility of these fishes to exploitation and future human stressors and to conserve their roles in both deep-sea ecosystems and the marine carbon cycle.

Acknowledgements. We thank Allen Andrews for providing thoughts, ideas, and data for this work. We also thank Odd Bergstad for providing data for Coryphaenoides armatus, as well as Clive Trueman and Diana Shores from the University of Southampton for their help in providing enzyme data and metadata. We thank Robert O'Malley at Oregon State University for help in using Ocean Productivity data. Finally, we thank all the researchers that provided key data for this meta-analysis: Alisa Abookire, Valérie Allain, Allen Andrews, Steven E. Campana, Cassandra Brooks, Graeme Ewing, Chip Cotton, Alex Fogg, Mackenzie Gerringer, Alison Gould, Sergio Ragonese, Donna Kline, Tom Laidig, Milton Love, Ana Neves, Dan Nichol, Isaac Kaplan, Margaret Finch, Cassandra Brooks, Melissa Mahoney, Nuria Raventos, Mark Belchier, David Sampson, Cara Rodgveller, Kelly Robinson and Christoph Stransky (affiliations available upon request). NSF-OCE provided funding for this project (Grants \#1829612 and \#0727135). This is SOEST contribution number 11187.

\section{LITERATURE CITED}

Akita Y, Tachihara K (2019) Age, growth, and maturity of the Indian flathead Platycephalus indicus in the waters around Okinawa-jima Island, Japan. Ichthyol Res 66: $330-339$

Allain V, Lorance P (2000) Age estimation and growth of some deep-sea fish from the Northeast Atlantic Ocean. Cybium 24:7-16

* Alvarez D, Metcalfe N (2005) Catch-up growth and swimming performance in threespine sticklebacks (Gasterosteus aculeatus): seasonal changes in the cost of compensation. Can J Fish Aquat Sci 62:2169-2176

Anderson JT (1988) A review of size dependent survival during pre-recruit stages of fishes in relation to recruitment. J Northwest Atl Fish Sci 8:55-66

Anderson OF, Bagley NW, Hurst RJ, Francis MP, Clark MR, McMillan PJ (1998) Atlas of New Zealand fish and squid distributions from research bottom trawls. Technical Report No. 42. National Institute of Water and Atmos- pheric Research, Auckland

* Andrews AH, Cailliet GM, Coale KH (1999) Age and growth of the Pacific grenadier (Coryphaenoides acrolepis) with age estimate validation using an improved radiometric ageing technique. Can J Fish Aquat Sci 56: 1339-1350

Armsworthy SL, Campana SE (2010) Age determination, bomb-radiocarbon validation and growth of Atlantic halibut (Hippoglossus hippoglossus) from the Northwest Atlantic. Environ Biol Fishes 89:279-295

Auer SK, Salin K, Rudolf AM, Anderson GJ, Metcalfe NB (2015) The optimal combination of standard metabolic rate and aerobic scope for somatic growth depends on food availability. Funct Ecol 29:479-486

Auer SK, Dick CA, Metcalfe NB, Reznick DN (2018) Metabolic rate evolves rapidly and in parallel with the pace of life history. Nat Commun 9:14

Bailey DM, Collins MA, Gordon JDM, Zuur AF, Priede IG (2009) Long-term changes in deep-water fish populations in the northeast Atlantic: A deeper reaching effect of fisheries? Proc R Soc B 276:1965-1969

Barton K (2019) MuMIn: multi-model inference. R package version 1.43.15. https://CRAN.R-project.org/package= MuMIn

* Bergstad O (2013) North Atlantic demersal deep-water fish distribution and biology: present knowledge and challenges for the future. J Fish Biol 83:1489-1507

*Booth AJ (1997) On the life history of the lesser gurnard (Scorpaeniformes: Triglidae) inhabiting the Agulhas Bank, South Africa. J Fish Biol 51:1155-1173

Booth AJ, Walmsley-Hart SA (2000) Biology of the redspotted tonguesole Cynoglossus zanzibarensis (Pleuronectiformes: Cynoglossidae) on the Agulhas Bank, South Africa. S Afr J Mar Sci 22:185-197

* Braaten PJ, Guy CS (2002) Life history attributes of fishes along the latitudinal gradient of the Missouri River. Trans Am Fish Soc 131:931-945

*Bill RW (1996) Selective advantages conferred by the high performance physiology of tunas, billfishes, and dolphin fish. Comp Biochem Physiol Part A Physiol 113:3-15

Brown JH, Gillooly JF, Allen AP, Savage VM, West GB (2004) Toward a metabolic theory of ecology. Ecology 85: 1771-1789

Cailliet GM, Andrews AH, Burton EJ, Watters DL, Kline DE, Ferry-Graham LA (2001) Age determination and validation studies of marine fishes: Do deep-dwellers live longer? Exp Gerontol 36:739-764

Campana SE (2001) Accuracy, precision and quality control in age determination, including a review of the use and abuse of age validation methods. J Fish Biol 59:197-242

Careau V, Thomas D, Humphries MM, Réale D (2008) Energy metabolism and animal personality. Oikos 117: 641-653

Cassia M (2000) Age and growth of the southern blue whiting Micromesistius australis in the SW Atlantic. Sci Mar 64:269-274

Childress JJ (1995) Are there physiological and biochemical adaptations of metabolism in deep-sea animals? Trends Ecol Evol 10:30-36

Childress J, Taylor S, Cailliet GM, Price M (1980) Patterns of growth, energy utilization and reproduction in some meso-and bathypelagic fishes off southern California. Mar Biol 61:27-40

Cohen DM, Inada T, Iwamoto T, Scialabba N (1990) Gadiform fishes of the world (Order Gadiformes): an anno- 
tated and illustrated catalogue of cods, hakes, grenadiers and other gadiform fishes known to date. FAO, Rome

N'Onghia G, Tursi A, Marano CA, Basanisi M (1998) Life history traits of Hoplostethus mediterraneus (Pisces: Beryciformes) from the north-western Ionian Sea (Mediterranean Sea). J Mar Biol Assoc UK 78:321-339

* D'Onghia G, Basanisi M, Tursi A (2000) Population structure, age and growth of macrourid fish from the upper slope of the eastern-central Mediterranean. J Fish Biol 56:1217-1238

Dahlhoff EP (2004) Biochemical indicators of stress and metabolism: applications for marine ecological studies. Annu Rev Physiol 66:183-207

* Damsgård B, Evensen TH, Øverli Ø, Gorissen M, Ebbesson LO, Rey S, Höglund E (2019) Proactive avoidance behaviour and pace-of-life syndrome in Atlantic salmon. R Soc Open Sci 6:181859

de Santana HS, Dei Tos C, Minte-Vera CV (2020) A review on the age and growth studies of freshwater fish in South America. Fish Res 222:105410

Drazen JC, Haedrich RL (2012) A continuum of life histories in deep-sea demersal fishes. Deep Sea Res I 61:34-42

* Drazen JC, Seibel BA (2007) Depth-related trends in metabolism of benthic and benthopelagic deep-sea fishes. Limnol Oceanogr 52:2306-2316

Drazen JC, Sutton TT (2017) Dining in the deep: the feeding ecology of deep-sea fishes. Annu Rev Mar Sci 9:337-366

* Drazen JC, Bailey DM, Ruhl HA, Smith KL Jr (2012) The role of carrion supply in the abundance of deep-water fish off California. PLOS ONE 7:e49332

Drazen JC, Friedman JR, Condon NE, Aus EJ, Gerringer ME, Keller AA, Clarke ME (2015) Enzyme activities of demersal fishes from the shelf to the abyssal plain. Deep Sea Res I 100:117-126

Dunn MR (2009) Review and stock assessment of black cardinalfish (Epigonus telescopus) on the east coast North Island, New Zealand. New Zealand Fisheries Assessment Report 2009/39. Ministry of Fisheries, Wellington

Dwyer KS, Treble MA, Campana SE (2016) Age and growth of Greenland halibut (Reinhardtius hippoglossoides) in the Northwest Atlantic: a changing perception based on bomb radiocarbon analyses. Fish Res 179:342-350

Everson I, Murray A (1999) Size at sexual maturity of Patagonian toothfish. CCAMLR Sci 6:37-46

Ewing GP, Lyle JM, Murphy RJ, Kalish JM, Ziegler PE (2007) Validation of age and growth in a long-lived temperate reef fish using otolith structure, oxytetracycline and bomb radiocarbon methods. Mar Freshw Res 58:944-955

Färber L, van Gemert R, Langangen Ø, Durant JM, Andersen KH (2020) Population variability under stressors is dependent on body mass growth and asymptotic body size. R Soc Open Sci 7:192011

Filer KR, Sedberry GR (2008) Age, growth and reproduction of the barrelfish Hyperoglyphe perciformis (Mitchill) in the western North Atlantic. J Fish Biol 72:861-882

Fogg A (2017) Life history of the non-native invasive red lionfish (Pterois volitans) in the northern Gulf of Mexico. MSc thesis, University of Southern Mississippi, Hattiesburg, MS

Friedman JR, Condon NE, Drazen JC (2012) Gill surface area and metabolic enzyme activities of demersal fishes associated with the oxygen minimum zone off California. Limnol Oceanogr 57:1701-1710

Friess C, Sedberry GR (2011) Age, growth, and spawning season of red bream (Beryx decadactylus) off the south- eastern United States. Fish Bull 109:20-33

Froese R, Pauly D (eds) (2019) FishBase. www.fishbase.org

Gallo ND, Levin LA (2016) Fish ecology and evolution in the world's oxygen minimum zones and implications of ocean deoxygenation. Adv Mar Biol 74:117-198

García VB, Lucifora LO, Myers RA (2008) The importance of habitat and life history to extinction risk in sharks, skates, rays and chimaeras. Proc R Soc B 275:83-89

García HE, Boyer TP, Locarnini RA, Antonov JI and others (2013) World Ocean Atlas 2013, Vol 3: dissolved oxygen, apparent oxygen utilization, and oxygen saturation. NOAA Atlas NESDIS 75

Gerringer ME, Drazen JC, Yancey PH (2017) Metabolic enzyme activities of abyssal and hadal fishes: pressure effects and a re-evaluation of depth-related changes. Deep Sea Res I 125:135-146

* Gerringer ME, Andrews AH, Huss GR, Nagashima K and others (2018) Life history of abyssal and hadal fishes from otolith growth zones and oxygen isotopic compositions. Deep Sea Res I 132:37-50

Gillooly JF, Brown JH, West GB, Savage VM, Charnov EL (2001) Effects of size and temperature on metabolic rate. Science 293:2248-2251

G Glover AG, Smith CR (2003) The deep-sea floor ecosystem: current status and prospects of anthropogenic change by the year 2025. Environ Conserv 30:219-241

*Gove JM, McManus MA, Neuheimer AB, Polovina JJ and others (2016) Near-island biological hotspots in barren ocean basins. Nat Commun 7:10581

* Gray JS, Wu RS, Or YY (2002) Effects of hypoxia and organic enrichment on the coastal marine environment. Mar Ecol Prog Ser 238:249-279

* Hartig F (2019) DHARMa: residual diagnostics for hierarchical (multi-level/mixed) regression models. R package version 0.2.6. https://CRAN.R-project.org/package= DHARMa

*Hector KL, Nakagawa S (2012) Quantitative analysis of compensatory and catch-up growth in diverse taxa. J Anim Ecol 81:583-593

KHorn PL (2002) Age and growth of Patagonian toothfish (Dissostichus eleginoides) and Antarctic toothfish (D. mawsoni) in waters from the New Zealand subantarctic to the Ross Sea, Antarctica. Fish Res 56:275-287

*Horn PL, Sullivan KJ (1996) Validated aging methodology using otoliths, and growth parameters for hoki (Macruronus novaezelandiae) in New Zealand waters. NZ J Mar Freshw Res 30:161-174

* Horn PL, Sutton CP (2015) An assessment of age and growth of violet cod (Antimora rostrata) in the Ross Sea, Antarctica. Polar Biol 38:1553-1558

Horn P, Neil H, Paul L, McMillan P (2012) Age verification, growth and life history of rubyfish Plagiogeneion rubiginosum. NZ J Mar Freshw Res 46:353-368

Jacobson LD, Brodziak J, Rogers J (2001) Depth distributions and time-varying bottom trawl selectivities for Dover sole (Microstomus pacificus), sablefish (Anoplopoma fimbria), and thornyheads (Sebastolobus alascanus and $S$. altivelis) in a commercial fishery. Fish Bull 99: 309-327

Jahnke RA (1996) The global ocean flux of particulate organic carbon: areal distribution and magnitude. Global Biogeochem Cycles 10:71-88

Jobling M (1997) Temperature and growth: modulation of growth rate via temperature change. In: Wood CM, McDonald DG (eds) Global warming: implications for 
freshwater and marine fish. Cambridge University Press, Cambridge, p 225-253

Jobling M (2010) Are compensatory growth and catch-up growth two sides of the same coin? Aquacult Int 18: 501-510

Juan-Jordá MJ, Mosqueira I, Freire J, Dulvy NK (2015) Population declines of tuna and relatives depend on their speed of life. Proc R Soc B 282:20150322

Killen SS (2014) Growth trajectory influences temperature preference in fish through an effect on metabolic rate. J Anim Ecol 83:1513-1522

Killen SS, Atkinson D, Glazier DS (2010) The intraspecific scaling of metabolic rate with body mass in fishes depends on lifestyle and temperature. Ecol Lett 13:184-193

Kline DE (1996) Radiochemical age verification for two deepsea rockfishes: Sebastolobus altivelis and S. alascanus. MSc thesis, San Jose State University, San Jose, CA

Koslow JA (1996) Energetic and life-history patterns of deep-sea benthic, benthopelagic and seamount-associated fish. J Fish Biol 49:54-74

Koslow J, Boehlert GW, Gordon JDM, Haedrich RL, Lorance P, Parin N (2000) Continental slope and deep-sea fisheries: implications for a fragile ecosystem. ICES J Mar Sci 57: 548-557

Laidig TE, Pearson DE, Sinclair LL (2003) Age and growth of blue rockfish (Sebastes mystinus) from central and northern California. Fish Bull 101:800-808

Labropoulou M, Papaconstantinou C (2000) Comparison of otolith growth and somatic growth in two macrourid fishes. Fish Res 46:177-188

Le Pape O, Bonhommeau S (2015) The food limitation hypothesis for juvenile marine fish. Fish Fish 16:373-398

Lehodey P, Grandperrin R (1996) Age and growth of the alfonsino Beryx splendens over the seamounts off New Caledonia. Mar Biol 125:249-258

Lima ID, Lam PJ, Doney SC (2013) Dynamics of particulate organic carbon flux in a global ocean model. Biogeosciences Discuss 10:14715-14767

Locarnini RA, Mishonov AV, Antonov JI, Boyer TP and others (2013) World Ocean Atlas 2013, Vol 1: temperature. NOAA Atlas NESDIS 73

Lorenzen K (1996) A simple von Bertalanffy model for density-dependent growth in extensive aquaculture, with an application to common carp (Cyprinus carpio). Aquaculture 142:191-205

Love MS, McCrea M, Kui L (2018) Aspects of the life histories of pinkrose rockfish (Sebastes simulator) and swordspine rockfish (Sebastes ensifer) with notes on the subgenus Sebastomus. Bull South Calif Acad Sci 117:64-76

Lutz MJ, Caldeira K, Dunbar RB, Behrenfeld MJ (2007) Seasonal rhythms of net primary production and particulate organic carbon flux to depth describe the efficiency of biological pump in the global ocean. J Geophys Res Oceans 112:C10011

Magnússon JV (2001) Distribution and some other biological parameters of two morid species Lepidion eques (Günther, 1887) and Antimora rostrata (Günther, 1878) in Icelandic waters. Fisheries Research 51:267-281.

Martin JH, Knauer GA, Karl DM, Broenkow WW (1987) VERTEX: carbon cycling in the northeast Pacific. DeepSea Res A 34:267-285

Massey BR, Horn PL (1990) Growth and age structure of alfonsino (Beryx splendens) from the lower east coast, North Island, New Zealand. NZ J Mar Freshw Res 24: 121-136
Massutí E, Morales-Nin B, Stefanescu C (1995) Distribution and biology of five grenadier fish (Pisces: Macrouridae) from the upper and middle slope of the northwestern Mediterranean. Deep Sea Res I 42:307-330

Matsui T, Kato S, Smith SE (1990) Biology and potential use of Pacific grenadier, Coryphaenoides acrolepis, off California. Mar Fish Rev 52:1-17

McClain CR, Allen AP, Tittensor DP, Rex MA (2012) Energetics of life on the deep seafloor. Proc Natl Acad Sci USA 109:15366-15371

McPhail AS (1998) Biology and management of the Cape Gurnard, Chelidonichthys capensis (Order Scorpaeniformes, Family Triglidae) in South Africa. PhD thesis, Rhodes University, Grahamstown

Metcalfe NB, Bull CD, Mangel M (2002) Seasonal variation in catch-up growth reveals state-dependent somatic allocations in salmon. Evol Ecol Res 4:871-881

Milligan RJ, Scott EM, Jones DO, Bett BJ and others (2020) Evidence for seasonal cycles in deep-sea fish abundances: A great migration in the deep SE Atlantic? J Anim Ecol 89:1593-1603

Mittelbach GG, Ballew NG, Kjelvik MK (2014) Fish behavioral types and their ecological consequences. Can J Fish Aquat Sci 71:927-944

*Morato T, Hoyle SD, Allain V, Nicol SJ (2010) Seamounts are hotspots of pelagic biodiversity in the open ocean. Proc Natl Acad Sci USA 107:9707-9711

Neuheimer AB, Grønkjær P (2012) Climate effects on sizeat-age: growth in warming waters compensates for earlier maturity in an exploited marine fish. Glob Change Biol 18:1812-1822

Neuheimer AB, Taggart CT (2007) The growing degree-day and fish size-at-age: the overlooked metric. Can J Fish Aquat Sci 64:375-385

*Neuheimer AB, Taggart CT (2010) Can changes in lengthat-age and maturation timing in Scotian Shelf haddock (Melanogrammus aeglefinus) be explained by fishing? Can J Fish Aquat Sci 67:854-865

*Neuheimer AB, Thresher RE, Lyle JM, Semmens JM (2011) Tolerance limit for fish growth exceeded by warming waters. Nat Clim Chang 1:110-113

Nichol DG (1990) Life history examination of darkblotched rockfish (Sebastes crameri) off the Oregon coast. MSc thesis, Oregon State University, Corvallis, OR

Orlov A, Vedishcheva E, Trofimova A, Orlova SY (2018) Age and growth of blue antimora Antimora rostrata (Moridae) in southwestern Greenland waters. J Ichthyol 58: $217-225$

Paul LJ, Horn PL (2009) Age and growth of sea perch (Helicolenus percoides) from two adjacent areas off the east coast of South Island, New Zealand. Fish Res 95: $169-180$

*Paulmier A, Ruiz-Pino D (2009) Oxygen minimum zones (OMZs) in the modern ocean. Prog Oceanogr 80:113-128

Persson L, De Roos AM (2006) Food-dependent individual growth and population dynamics in fishes. J Fish Biol 69(Suppl C):1-20

* Piñeiro C, Saínza M (2003) Age estimation, growth and maturity of the European hake (Merluccius merluccius (Linnaeus, 1758)) from Iberian Atlantic waters. ICES J Mar Sci 60:1086-1102

Pinsky ML, Byler D (2015) Fishing, fast growth and climate variability increase the risk of collapse. Proc R Soc B 282: 20151053

Pörtner HO, Knust R (2007) Climate change affects marine 
fishes through the oxygen limitation of thermal tolerance. Science 315:95-97

Priede IG, Froese R (2013) Colonization of the deep sea by fishes. J Fish Biol 83:1528-1550

Rall BC, Brose U, Hartvig M, Kalinkat G, Schwarzmüller F, Vucic-Pestic O, Petchey OL (2012) Universal temperature and body-mass scaling of feeding rates. Philos Trans R Soc B 367:2923-2934

Réale D, Garant D, Humphries MM, Bergeron P, Careau V, Montiglio PO (2010) Personality and the emergence of the pace-of-life syndrome concept at the population level. Philos Trans R Soc B 365:4051-4063

Rideout RM, Ings DW, Healey BP, Brattey $\mathrm{J}$ and others (2016) Assessing the status of the cod (Gadus morhua) stock in NAFO Subdivision 3Ps in 2013 and 2014. DFO Can Sci Advis Sec Res Doc

Rigby C, Simpfendorfer CA (2015) Patterns in life history traits of deep-water chondrichthyans. Deep Sea Res II 115:30-40

Rypel AL (2012) Meta-analysis of growth rates for a circumpolar fish, the northern pike (Esox lucius), with emphasis on effects of continent, climate and latitude. Ecol Freshwat Fish 21:521-532

* Saavedra LM, Quiñones RA, Gonzalez-Saldía RR, Niklitschek EJ (2016) Aerobic and anaerobic enzymatic activity of orange roughy (Hoplostethus atlanticus) and alfonsino (Beryx splendens) from the Juan Fernandez seamounts area. Fish Physiol Biochem 42:869-882

Saborido-Rey F, Garabana D, Cervino S (2004) Age and growth of redfish (Sebastes marinus, S. mentella, and $S$. fasciatus) on the Flemish Cap (Northwest Atlantic) ICES J Mar Sci 61:231-242

Scarcella G, La Mesa M, Grati F, Polidori P (2011) Age and growth of the small red scorpionfish, Scorpaena notata Rafinesque, 1810, based on whole and sectioned otolith readings. Environ Biol Fish 91:369

* Schwarz R, Piatkowski U, Hoving HJT (2018) Impact of environmental temperature on the lifespan of octopods. Mar Ecol Prog Ser 605:151-164

Sebens KP (1987) The ecology of indeterminate growth in animals. Annu Rev Ecol Syst 18:371-407

Shackell NL, Ferguson KJ, den Heyer CE, Brickman D, Wang Z, Ransier KT (2019) Growing degree-day influences growth rate and length of maturity of Northwest Atlantic halibut (Hippoglossus hippoglussus L.) across the southern stock domain. J Northwest Atl Fish Sci 50: 25-35

Siebenaller J, Somero G, Haedrich R (1982) Biochemical characteristics of macrourid fishes differing in their depths of distribution. Biol Bull (Woods Hole) 163:240-249

Smith K Jr (1992) Benthic boundary layer communities and carbon cycling at abyssal depths in the central North Pacific. Limnol Oceanogr 37:1034-1056

Smith CR, Demopoulos AW (2003) The deep Pacific ocean floor. In: Tyler PA (ed) Ecosystems of the world, Vol 28. Ecosystems of the deep oceans. Elsevier, Amsterdam, p 179-218

Smith D, Stewart B (1994) Development of methods to age commercially important dories and oreos. Final report to Fisheries Research and Development Corporation, PROJECT 91:36

Somero GN (1990) Life at low volume change: hydrostatic pressure as a selective factor in the aquatic environment. Am Zool 30:123-135

Somero GN, Childress JJ (1980) A violation of the metabo- lism-size scaling paradigm: activities of glycolytic enzymes in muscle increase in larger-size fish. Physiol Zool 53:322-337

Stevens MM, Andrews AH, Cailliet GM, Coale KH, Lundstrom CC (2004) Radiometric validation of age, growth, and longevity for the blackgill rockfish (Sebastes melanostomus). Fish Bull 102:711-722

Stewart BD, Fenton GE, Smith DC, Short SA (1995) Validation of otolith-increment age estimates for a deepwater fish species, the warty oreo Allocyttus verrucosus, by radiometric analysis. Mar Biol 123:29-38

* Stransky C, Gudmundsdottir S, Sigurdsson T, Lemvig S, Nedreaas K, Saborido-Rey F (2005) Age determination and growth of Atlantic redfish ( $S$. marinus and $S$. mentella): bias and precision of age readers and otolith preparation methods. ICES J Mar Sci 62:655-670

* Stratmann T, Lins L, Purser A, Marcon Y and others (2018) Abyssal plain faunal carbon flows remain depressed 26 years after a simulated deep-sea mining disturbance. Biogeosciences 15:4131-4145

Stratmann T, Soetaert K, Wei CL, Lin YS, van Oevelen D (2019) The SCOC database, a large, open, and global database with sediment community oxygen consumption rates. Sci Data 6:242

Sullivan KM, Somero GN (1980) Enzyme activities of fish skeletal muscle and brain as influenced by depth of occurrence and habits of feeding and locomotion. Mar Biol 60:91-99

Sutton CP, Tracey DM, Andrews AH, Hart AC, MacGibbon DJ (2010) Validated age and growth of ribaldo (Mora moro). New Zealand Fisheries Assessment Report No. 2010/24. Ministry of Fisheries, Wellington

Sweetman AK, Thurber AR, Smith CR, Levin LA and others (2017) Major impacts of climate change on deep-sea benthic ecosystems. Elem Sci Anth 5:4

Thresher RE, Koslow J, Morison A, Smith D (2007) Depthmediated reversal of the effects of climate change on long-term growth rates of exploited marine fish. Proc Natl Acad Sci USA 104:7461-7465

Tracey DM, George K, Gilbert DJ (2000) Estimation of age, growth, and mortality parameters of black cardinalfish (Epigonus telescopus) in QMA 2 (east coast North Island). Ministry of Fisheries, Wellington

* Tracey DM, Andrews AH, Horn PL, Neil HL (2017) Another New Zealand centenarian: age validation of black cardinalfish (Epigonus telescopus) using leadradium and bomb radiocarbon dating. Mar Freshw Res 68:352-360

Treberg JR, Speers-Roesch B (2016) Does the physiology of chondrichthyan fishes constrain their distribution in the deep sea? J Exp Biol 219:615-625

* Trueman CN, Johnston G, O'Hea B, MacKenzie KM (2014) Trophic interactions of fish communities at midwater depths enhance long-term carbon storage and benthic production on continental slopes. Proc R Soc B 281: 20140669

*Van der Have TM, De Jong G (1996) Adult size in ectotherms: temperature effects on growth and differentiation. J Theor Biol 183:329-340

Van Wijk EM, Williams R, Constable AJ (2003) Age, growth and size at sexual maturity of Macrourus carinatus caught as by-catch in Australian sub-Antarctic trawl fisheries. CCAMLR Sci 10:139-151

Vaz-dos-Santos AM, Lúcia C, Rossi-Wongtschowski DB (2007) Age and growth of the Argentine hake Merluccius 
hubbsi Marini, 1933 in the Brazilian south-southeast region during 1996-2001. Neotrop Ichthyol 5:375-386

Venturelli PA, Lester NP, Marshall TR, Shuter BJ (2010) Consistent patterns of maturity and density-dependent growth among populations of walleye (Sander vitreus): application of the growing degree-day metric. Can J Fish Aquat Sci 67:1057-1067

von Bertalanffy L (1938) A quantitative theory of organic growth (inquiries on growth laws. II). Human Biol 10: $181-213$

Editorial responsibility: Myron Peck,

Hamburg, Germany

Reviewed by: $M$. Priede and 2 anonymous referees
Woolley SNC, Tittensor DP, Dunstan PK, Guillera-Arroita G and others (2016) Deep-sea diversity patterns are shaped by energy availability. Nature 533:393-396

KYancey PH, Siebenaller JF (2015) Co-evolution of proteins and solutions: protein adaptation versus cytoprotective micromolecules and their roles in marine organisms. J Exp Biol 218:1880-1896

* Zuur AF, Ieno EN, Elphick CS (2010) A protocol for data exploration to avoid common statistical problems. Methods Ecol Evol 1:3-14

Submitted: July 22, 2020

Accepted: November 20, 2020

Proofs received from author(s): January 19, 2021 